Archive for

Organic Chemistry

Arkivoc 2017, part iii, 105-120

\title{
Synthesis of novel Y-shaped asymmetrical conjugated 2,4,6-trisubstituted pyrimidines and investigation of their optical and electrochemical properties
}

\author{
Ekaterina A. Komissarova, ${ }^{\text {a,c }}$ Evgenii Sosnin, ${ }^{b}$ Elena V. Shklyaeva, ${ }^{\text {b,c }}$ Irina V. Osorgina, ${ }^{c}$ and Georgii G. \\ Abashev*a,c
}

anstitute of Technical Chemistry, Ural Branch of the Russian Academy of Sciences, Perm, Ac. Koroleva Str. 3, Perm 614013, Russia

bInstitute of Natural Science of Perm State University, Perm, Genkel Str. 4, Perm 614990, Russia

${ }^{c}$ Perm State University, Perm, Bukireva Str. 15, Perm 614990, Russia

Email: gabashev@psu.ru

\section{Dedicated to Prof. Oleg A. Rakitin on the occasion of his $65^{\text {th }}$ birthday}

Received 12-09-2016

Accepted 01-22-2017

Published on line $04-10-2017$

\section{Abstract}

A set of novel Y-shaped asymmetrical pyrimidines has been prepared on the basis of 2-hydroxy-4,6dimethylpyrimidine used as a starting compound. All of them are the chromophores of $D-\pi-A-\pi-D^{\prime}$ motif where $A$ is a central pyrimidine core; $D, D^{\prime}$ are the thiophene-2-yl, thiophene-3-yl, 9-ethyl-9H-carbazol-3-yl or $9 H$-carbazole-9-yl- fragments and a $\pi$-bridge is a vinyl or styryl moiety. We have studied their optical, electrochemical and electrophysical characteristics, as well as their polymerizability with the help of electrochemical oxidation.
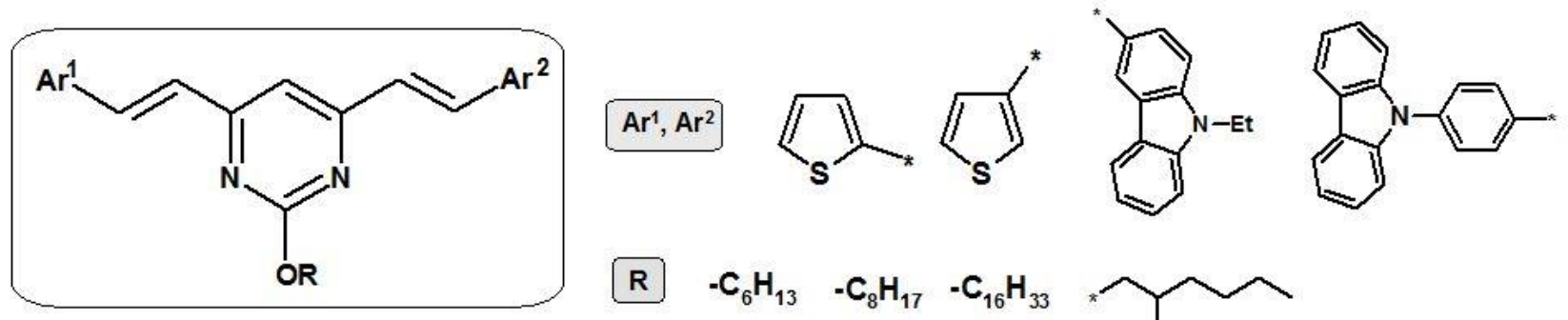

$R \quad-\mathrm{C}_{6} \mathrm{H}_{13} \quad-\mathrm{C}_{8} \mathrm{H}_{17} \quad-\mathrm{C}_{16} \mathrm{H}_{33} \quad \overbrace{}^{-}$

Keywords: Thiophene, carbazole, pyrimidine, chromophore, thin films, electrochemical oxidation, cyclic voltammetry, UV-viz spectroscopy, fluorescence, HOMO-LUMO gap, frontier orbitals 


\section{Introduction}

Organic electronics is moving at an incredible speed involving in the sphere of use and interest more and more new organic compounds among which $\pi$-conjugated systems (small molecules, oligomers and polymers) hold a special place. ${ }^{1-5}$ The $\pi$-conjugated compounds, which structure includes simultaneously electron excessive (D) and electron deficient (A) moieties, the so-called push-pull chromophores, are extensively studied and used in material chemistry. Usually they display an effective intramolecular charge transfer (ICT), that is important in terms of their application as materials for nonlinear optics (NLO), for organic light emitting diodes (OLED) and fluorescent sensors. ${ }^{6-8}$ At the same time it is known that most of the materials based on $\pi$ conjugated organic compounds exhibit p-type of conductivity, whereas the organic photovoltaics requires the stable materials with n-type of conductivity. Alternating donor/acceptor units in the main chain of a chromophore structure, embedding electron acceptor or electron donor fragments into the side chains, changing the nature and the ratio of D/A fragments in a conjugation chain and, modifying the character of $\pi$ bridges as well, make it possible to generate a compound with the required optical, physical, chemical and electrical properties. ${ }^{9-13}$ Such an interesting line of research as synthesis and investigation of pyrimidinecontaining chromophores of $D-A, D-A-D, D-\pi-A, D-\pi-A-\pi-D$ motifs is intensively developing exactly in this context. ${ }^{12,14-21}$

There are various synthetic pathways towards preparation of substituted pyrimidines. ${ }^{22-23}$ One of them consists in condensation of aromatic aldehydes with 2-hydroxy-4,6-dimethylpyrimidine, which can be regarded as one of the important building blocks useful for constructing $D-\pi-A-\pi-D$ systems. This method permits to obtain $\pi$-conjugated 2-hydroxypyrimidines with vinylene bridges in $4 C$ and $6 C$ positions linking pyrimidine core with different aromatic units. As a result, a plenty of 2,4,6-trisubstiuted pyrimidines of $Y$ shaped (banana-shaped) structure have been synthesized. ${ }^{15-16,20,22-24}$ Due to the shape and spaitial arrangement these compounds frequently display nonlinear optical properties. ${ }^{7}$ Most of them are the chromophores with two-photon absorption (2PA), and as a consequence, can be applied in optical limiting, optical data storage, in two-photon fluorescence microscopy, and in photodynamic therapy of cancer. ${ }^{18,20,24-29}$ The existence of hydroxyl groups in the structure of these chromophores makes it possible to incorporate aliphatic substituents which improve their solubility and processability. Moreover, length, branching degree and the nature of O-substituents influence the character and strength of van der Waals interactions, which affect the spatial structure, degree of aggregation, stability in solutions and in the films of monomers and polymers derived from them. The presence of functional groups or aromatic moieties in these substituents could also change the structural, optical and electrokinetic characteristics of the monomers and polymers as well. $^{30-32}$ There have already been described 4,6-substituted pyrimidines including phenothiazine ${ }^{33}$, thiophene ${ }^{34}$, triphenylamine ${ }^{20}$, methoxynaphthalene, ${ }^{7} \mathrm{~N}$-ethylcarbazole, ${ }^{35-36} \mathrm{~N}$-vinylcarbazole ${ }^{37}$ fragments linked with a pyrimidine ring via bridges of various structure (Figure 1): 


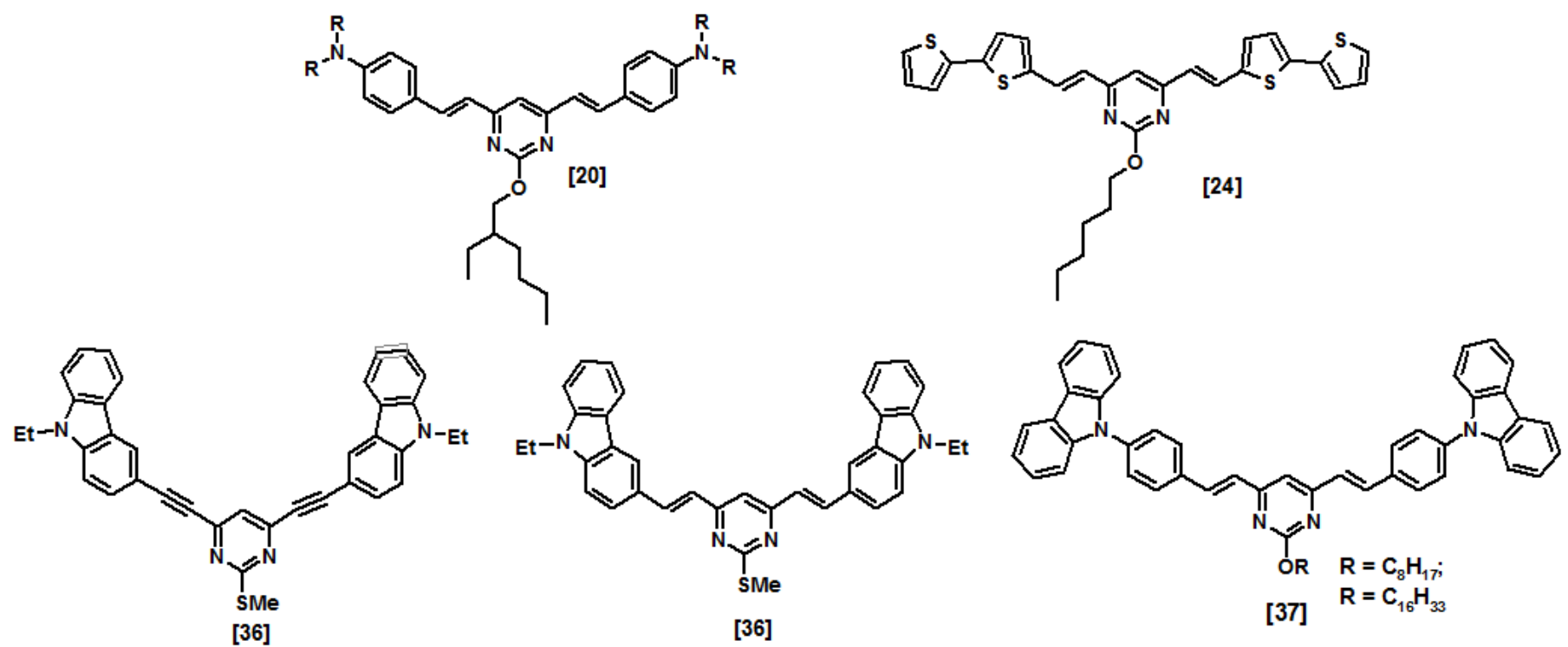

Figure 1. Examples of the synthesized Y-shaped pyrimidines structures.

It should be noted that at present time the only symmetrical pyrimidines of this type have been synthesized and investigated. 20,24,36-37 The asymmetry of a molecule induces the redistribution of electron density, which entails the changes in physicochemical and optical properties. The character of these changes can be tuned in different ways, e.g. by incorporation of dissimilar substituents into the various positions of the carbo- or heterocyclic moiety of monomer, by the asymmetry of a central core or by creation of asymmetric periphery. ${ }^{37-39}$ Besides, the asymmetry of a molecule structure always affects the packing mode of compounds; for example, the oligothiophenes with different terminal aliphatic substituents have been found to form a liquid crystal phase even at an ordinary temperature that is a result of a molecular asymmetry. ${ }^{40}$

As part of our ongoing work w6,40 $^{36}$ we have prepared a series of asymmetrical 4,6-diaryl-substituted 2alkoxypyrimidines integrating in one molecule two different electron excessive heterocyclic moieties (Scheme 1). Synthesis of these compounds, containing carbazole, thiophene and pyrimidine moieties in various combination, their optical and electrochemical properties as well as their electrochemical polymerization are discussed in this paper.

\section{Results and Discussion}

Synthesis. As mentioned above, the reaction of 4,6-dimethyl substituted pyrimidines with aromatic aldehydes is usually applied to obtain symmetrical compounds ${ }^{33}$ and is rarely used to prepare asymmetrical compounds. ${ }^{41}$ The traditional usage of $1: 2$ mole ratio of reactants has given rise to a plenty of symmetrical 4,6di(2-arylvinyl)pyrimidines of Y-or V-shaped configuration. ${ }^{20,36,40}$ We have firstly carried out the stepwise condensation of thiophene- or carbazole-containing aldehydes ( $\mathrm{Ar}^{1} \mathrm{CHO}$ ) I-IV with 2-hydroxy-4,6dimethylpyrimidine $\mathbf{1}$, pre-synthesized by cyclization of acetyl acetone with urea (Scheme 1). ${ }^{42}$ The initial interaction of equimolar amounts of reagents has resulted in formation of 2-hydroxy-4-methyl-6-(2arylvinyl)pyrimidines hydrochlorides as the brick-red poorly-soluble crystalline substances, which further treatment with the potassium carbonate water-alcohol solution has brought about free bases 2-4 as yellow 
solid powders purified by the repeated washing with hot ethanol (pyrimidines $\mathbf{2}$ and $\mathbf{4}$ ) or by recrystallization from toluene (pyrimidine $\mathbf{3}$ ).
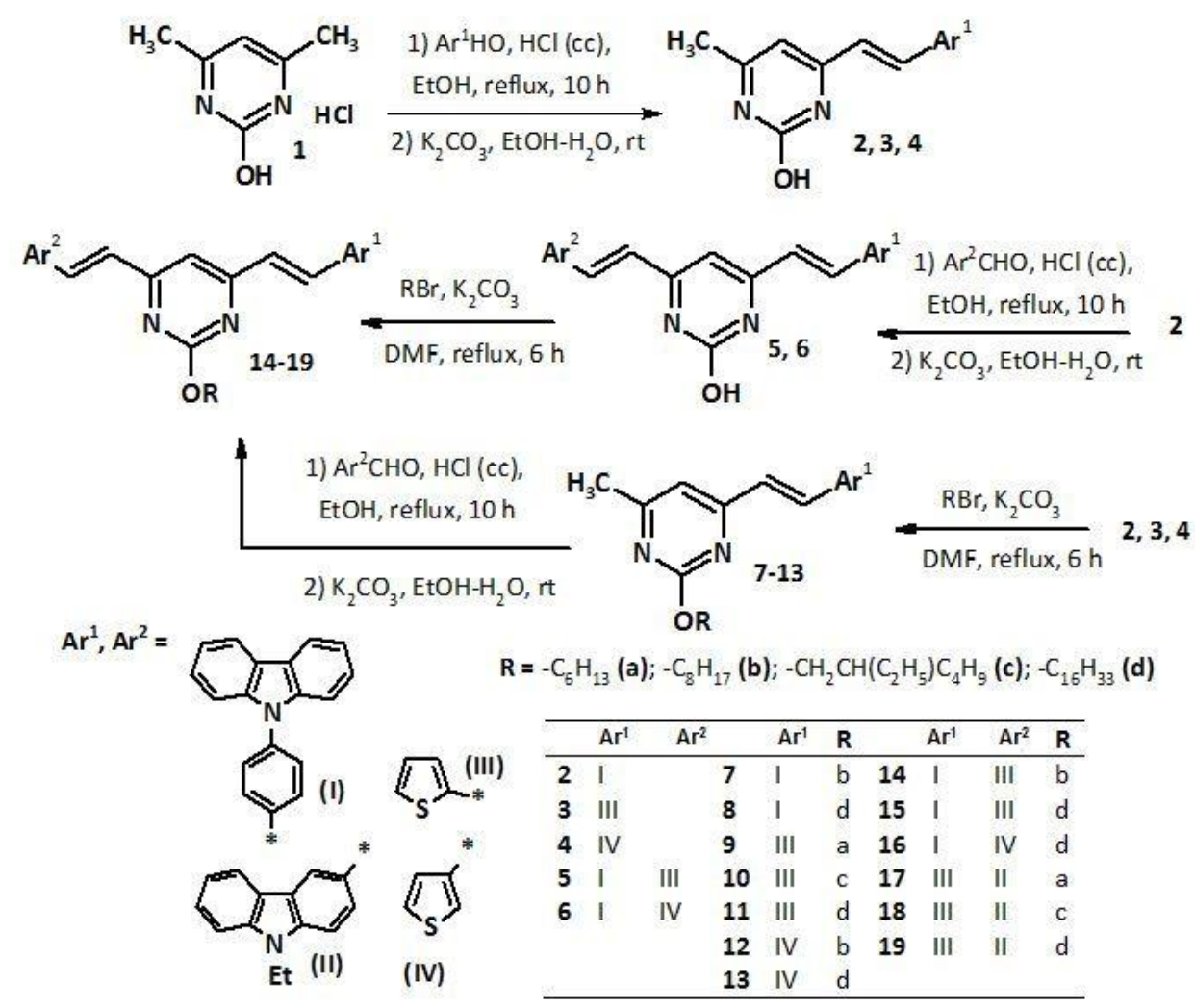

Scheme 1. Synthetic routes to the Y-shaped 4,6-disubstituted 2-hydroxy and 2-alkoxypyrimidines 14-19.

The remaining methyl group of the pyrimidines 2-4 and 7-13 can further participate in condensation with arylcarboxaldehydes, that opens the possibility to prepare asymmetric $Y$-shaped conjugated pyrimidines, in our case - the pyrimidines 14-19 (Scheme 1). We have explored two ways to create these structures.

The first approach involves the following sequent steps: the initial condensation of 2hydroxypyrimidines 2-4 with aldehydes I-IV in presence of $\mathrm{HCl}(\mathrm{cc})$, the isolation of 6-Ar ${ }^{1}-4-\mathrm{Ar}^{2}-2$ hydroxypyrimidines from the resulting hydrochlorides and finally the alkylation of a free hydroxy group to form the desired monomers - 6-Ar-4-Ar²-2-alkoxypyrimidines 14-19. However, this way appeared to be successful only in the case of pyrimidine $\mathbf{2}$ which reacted with thiophen carbaldehydes III and IV and gave rise to the intermediate asymmetrical bases $\mathbf{5}$ and $\mathbf{6}$ in good yields. That's why this synthetic approach might be regarded as a preparative method particularly because the further alkylation of pyrimidines 5 and 6 has resulted in the high-yield formation of asymmetrical 2-alkoxypyrimidines 14-16. $\operatorname{The}^{6-A r^{1}-4-A r^{2}-2-}$ alkoxypyrimidines 14-16 were obtained as yellow amorphous solids, readily soluble in common organic solvents.

The second sequence of the reactions is somewhat different (Scheme 1). It starts with O-alkylation of the pyrimidines 2-4 and results in formation of 2-alkoxy-4-methyl-6-Ar-pyrimidines 7-13 as yellow viscous substances (except 11) readily soluble in common organic solvents. Further condensations of these compounds with arylcarboxaldehydes have produced asymmetrical conjugated Y-shaped pyrimidines 17-19 containing different heterocyclic moieties at C4 and C6 atoms of a pyrimidine core. It should be noted that all 
the transformations in this series proceeded with high yields, although the main method of separation and purification of the synthesized compounds was the column chromatography.

All the prepared $\mathrm{Y}$-shaped pyrimidines 7-19 could be regarded as the extended $\pi$-conjugated chromophores of the D- $\pi-A-\pi-D^{\prime}$ motif and at the same time - as the $\pi$-conjugated oligomers, which backbone is formed by several aromatic heterocycles alternating in various manner. The values of their molecular weights lie in the interval 330-700. Optical and electrochemical properties of these compounds are dictated first of all by the interaction of a central electron defficient pyrimidine core with the electron-excessive conjugated arms in C4 and C6 positions of a pyrimidine cycle, "leading to antennae-type light harvesting from the arms followed by energy transfer to the core". ${ }^{1}$ The structure of an O-substitutent definetely affects the solubility and the tendency for aggregation, and finally determines the film-forming parameters of compounds and the characteristics of future thin films.

Absorption and emission properties. The resulting neat pyrimidines as well as their solutions are of bright red, yellow or orange colors. Moreover, most of the solutions fluoresce (e.g. Figure 5); thus the solutions of compounds 15-16 fluoresce even in the visible light to form solutions of the green-blue and deep violet color. The intensity of fluorescence and its duration increase sharply under UV irradiation (UV lamp, Camelion LY-26$\mathrm{fs} / \mathrm{blb} / \mathrm{e} 27, \lambda=365 \mathrm{~nm}$ ). The optical properties of pyrimidines have been studied by means of UV-vis absorption and fluorescence spectroscopy; the spectra have been registered for chloroform solutions. The results are summarized in Table 1. The corresponding absorption spectra are presented in Figures 2-3.

Table 1. Absorbance and emission data of the synthesized pyrimidines 5, 6, 14-19

\begin{tabular}{|c|c|c|c|c|c|}
\hline Comp & $\lambda_{\max }^{\mathrm{abs}}, \mathrm{nm}$ & $\lambda_{\text {onset, }} \mathrm{nm}$ & $\mathrm{E}_{\mathrm{g}}^{\mathrm{opt}}, \mathrm{eV}$ & $\lambda_{\max }^{\mathrm{emi}}, \mathrm{nm}$ & $\Delta v, \mathrm{~nm}$ \\
\hline 5 & $233,290,335,603$ & 742 & 1,67 & 550 & 215 \\
\hline 6 & $\begin{array}{c}237,290,325,434 \\
623\end{array}$ & 690 & 1,79 & 515 & 190 \\
\hline 14 & $273,303,325,618$ & 670 & 1,85 & 464 & 129 \\
\hline 15 & $235,290,323,623$ & 665 & 1,86 & 477 & 154 \\
\hline 16 & $238,292,321,585$ & 610 & 1,86 & 471 & 150 \\
\hline 17 & $\begin{array}{c}245,277,293,335 \\
402(\mathrm{brd})\end{array}$ & 450 & 2.75 & 420 & 85 \\
\hline 18 & $245,280,340$ & 435 & 2.85 & 445 & 105 \\
\hline 19 & $243,262,354$ & 506 & 2.45 & 425 & 73 \\
\hline
\end{tabular}

Four (5-6, 14-17) or three (18-19) main absorption maxima of various intensity are observed in UV-vis spectra of pyrimidines in chloroform (Table 1). Absorption spectra of the pyrimidines 2, 5-6, 14-16, containing 2-\{4-(carbazol-9-yl)phenyl\}vinyl moiety, are characterized by the appearance of a long wavelength absorption bands of a very low intensity in the range of $590-624 \mathrm{~nm}$ (Table 1, Figure 2). The origin of this band can be explained by the existence of an effective intramolecular charge transfer (ICT) from the 4-(carbazol-9-yl) unit to the central electron withdrawing pyrimidine cycle through the conjugated $-\mathrm{C}_{6} \mathrm{H}_{4}-\mathrm{C}(\mathrm{H})=\mathrm{CH}-$ bridge. This fact is in agreement with the previous results of investigations fulfilled by us $^{43}$ : the UV absorption spectra of symmetrical 2-hydrox/alkoxy-4,6-bis(2-\{4-(carbazol-9-yl)phenyl\}vinyl)pyrimidines also display the long wavelength bands of low intensity. The absoption UV-vis spectrum of 2-hydroxy-4,6-bis(2-\{4-(carbazol-9yl)phenyl\}vinyl)pyrimidine has such a low-intensity band at $520 \mathrm{~nm}$, its n-octyl ether - at $676 \mathrm{~nm}$ and $\mathrm{n}$ - 
hexadecyl ether - at $617 \mathrm{~nm}$. The UV spectra of compounds 17-19 don't display a long wavelength maxima despite the presence of such an electron-rich fragment as $N$-ethyl carbazole in their structure (Table 1, Figure 3). Furthermore, the absorption edge ( $\lambda^{\text {abs }}$ onset $)$ of pyrimidines $5-6,14-16$, containing 4-(carbazol-9-yl)phenyl moiety is strongly redshifted (Table 1 ).

The optical band gap energies $\left(\mathbf{E}_{\mathbf{g}}{ }^{\text {opt}}\right.$ ) of the resulting pyrimidines were calculated on the basis of the absorption edge values ( $\lambda^{\text {abs }}$ onset) by equation $E_{g}{ }^{\text {opt }}=1240 / \lambda^{\text {abs }}$ onset. Not surprisingly that in the case of pyrimidines 2, 5-6, 14-16 these values are less than $2 \mathrm{eV}$ (Table 1). The same fact has been previously found for a symmetric pyrimidines set in which $\mathbf{E}_{\mathbf{g}}{ }^{\text {opt }}$ lie in the interval 1.65-1.92 eV. ${ }^{36}$ For compounds 17-19 including 2-(9-ethyl-9H-carbazol-3-yl)vinyl moiety the $\mathbf{E}_{\mathbf{g}}{ }^{\text {opt }}$ values are definitely higher and fall into the range of 2.45 $2.85 \mathrm{eV}$.

The influence of the pyrimidines structure on the fluorescence spectra is nearly the same that has been found for the absorption spectra. The emission maxima of compounds $5, \mathbf{6 , 1 4 - 1 6}$ were found to be redshifted if compared with those of compounds 17-19. As in the case of UV spectra, the pyrimidines 5-6 containing free hydroxyl group show the highest $\lambda_{\max }{ }^{\text {emi }}$ values: $550 \mathrm{~nm}$ - for the 2-hydroxypyrimidine 5 and $515 \mathrm{~nm}$ - for $\mathbf{6}$. Most likely that here takes place the excited-state proton transfer (ESPT) and the hydrogen of the hydroxyl group moves to the adjacent nitrogen atom of a pyrimidine ring to form the system with the separate charges, which could be further stabilized by converting either into initial 2-hydroxypyrimidine system or into tautomeric 2-pyrimidinone system. Such a process is usually accompanied by intense emission in the red wavelength range of the spectrum. ${ }^{44-45}$

The Stokes shifts (SS) of the obtained set of pyrimidines vary from 73 (18) to $190 \mathrm{~nm}$ (6) (Table 1, Fig. 45). Such high values of shifts might be primarily explained by the existence in the compounds of the notable intramolecular charge transfer from electron rich fragments to electron deficient pyrimidine, which entails a change in the electron density distribution along the conjugation chain of a compound, that in its turn leads to a change of a dipole moment in the excited state. As a result, the solvent dipoles have to reorient around this new excited state dipole moment of fluorophore in order to attain a new energetically favorable orientation. $16,46-47$

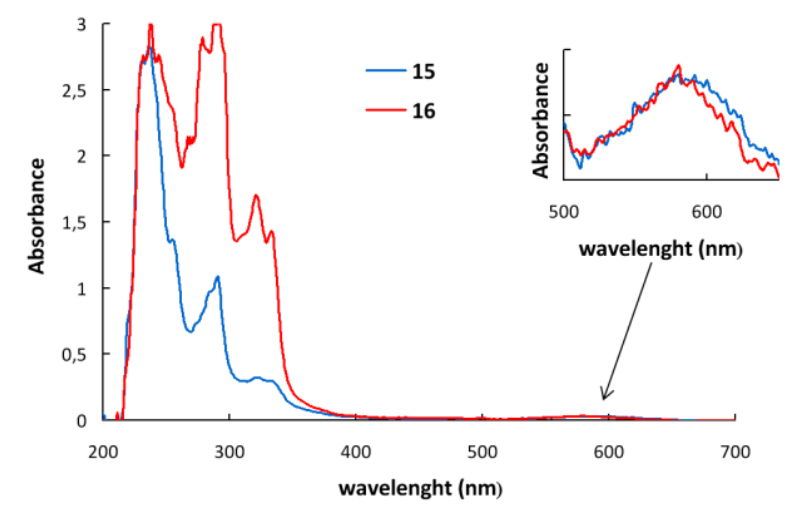

Figure 2. Absorption spectra of 15 (blue) and 16 (red) in $\mathrm{CHCl}_{3}$.

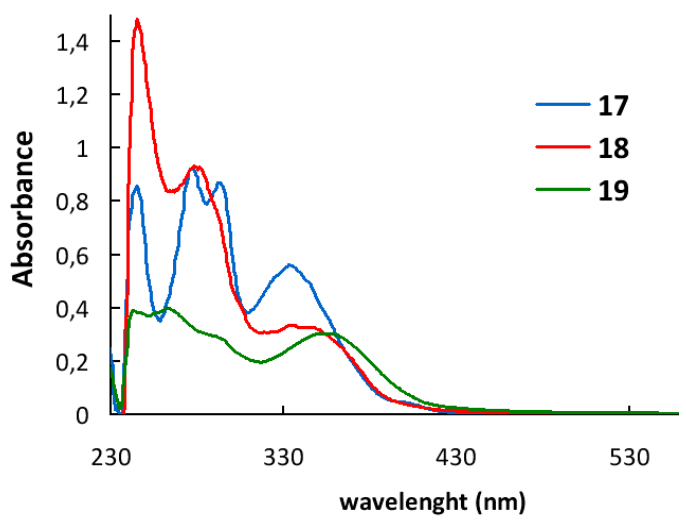

Figure 3. Absorption spectra of 17 (blue), 18 (red), 19 (green) in $\mathrm{CHCl}_{3}$. 


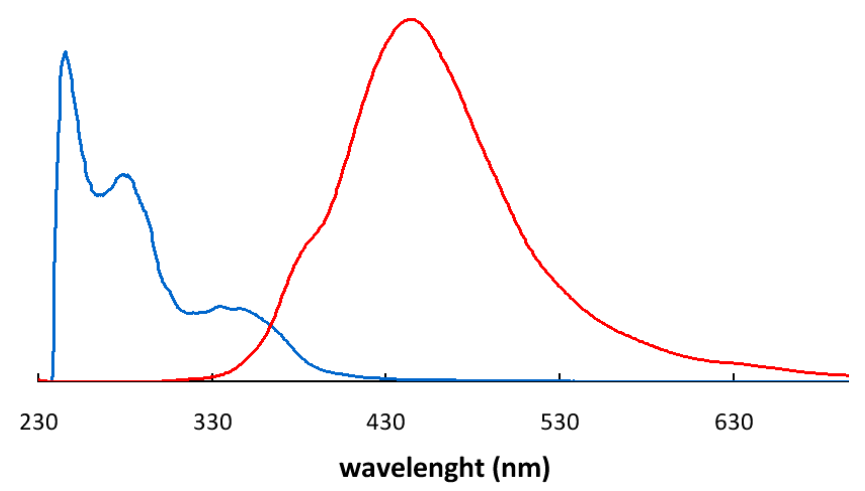

Figure 4. Absorption (blue) and fluorescence (red) spectra of 19 in $\mathrm{CHCl}_{3}$.

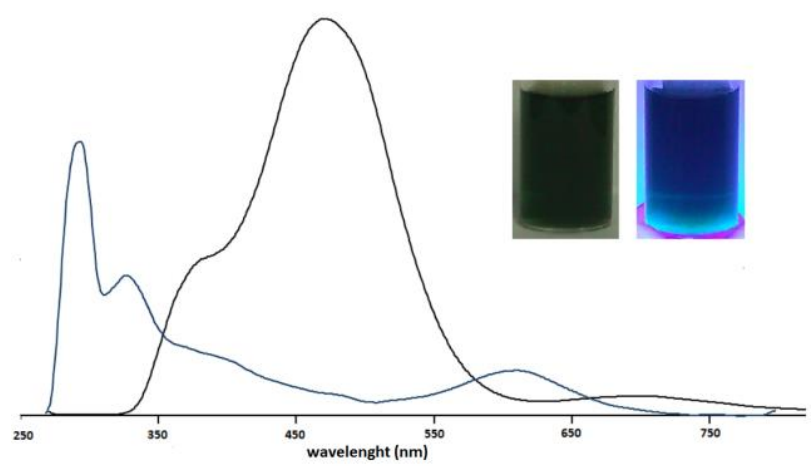

Figure 5. Absorption (blue) and fluorescence (black) spectra of $\mathbf{1 5}$ in $\mathrm{CHCl}_{3}$ Inset shows the colors of this compound under room light (left) and UV light (right) illumination ( $\lambda=365 \mathrm{~nm}$ ).

Cyclic voltammetry measurements. With an effort to gain further insights into electronic properties of the synthesized pyrimidines their redox behavior was studied with the help of cyclic voltammetry (CV). The details of CV experiments can be found in Experimental Section. In this work, all the synthesized compounds contain electron rich units (such as carbazole and thiophene) which could be polymerized chemically and electrochemically when their electron rich positions are free (C3 and C6 - in a carbazole moiety and C2 and C5 - in a thiophene one). Pyrimidines 2, 4-8 and 12-16 include such types of carbazole or/and thiophene fragments, that's why they successfully undergo electrochemical oxidation and form oligomer/polymer films on the surface of the working electrode. Here we present three examples of the obtained cyclic voltammograms (Figs. 6-8). The first two graphs are the CV of pyrimidines 8 and $\mathbf{1 5}$, one of which (8) is a precursor of the other one (15). Both compounds include such a polymerizable moiety as carbazole; at the same time compound $\mathbf{1 5}$ includes a thiophene moiety which also could be oxidized. As can be seen from Figs 6-7 the obtained CVs are practically identical. Both of them showed the irreversible one-electron oxidation waves. The values of $E^{o x}{ }_{\text {onset }}$ and $E^{\circ x}$ are 1.22, $1.28 \mathrm{~V}$ for 8 and 1.25, $1.28 \mathrm{~V}$ - for 15. This fact allows us to suppose that the polymerization process of pyrimidine $\mathbf{1 5}$ proceeds only through oxidation of a carbazole moiety. The indirect evidence of this assumption lies in the fact that the potential values $E^{\text {ox }}$ onset and $E^{o x}$ for such symmetrical compounds as 2-butoxy-4,6-di[2-(thiophene-2-yl)vinyl]pyrimidine and 2-hexadecyloxy-4.6bis(2-\{4-(carbazol-9-yl)phenyl\}vinylpyrimidine are 1.33 and $1.9 \mathrm{~V}^{43}$ and $0.83 \mathrm{~V}$ and $1.22 \mathrm{~V}^{37}$ (vs $\mathrm{Ag} / \mathrm{AgCl}$ ), consequently. Compound 12 has shown a reversible oxidation peak (Eox $-1,8 \mathrm{~V}$, Ered $=1,63 \mathrm{~V}$ ) and the oxidation process starts at about $1.3 \mathrm{~V}$.

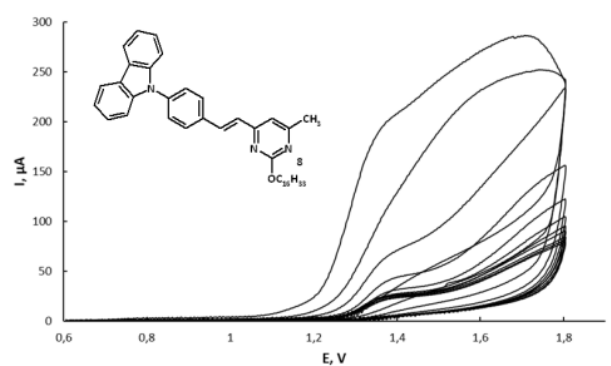

Figure 6. Cyclic voltammogram (10 cycles) of $\mathbf{8}$ (ITO electrode, $\mathrm{Et}_{4} \mathrm{NClO}_{4}, \mathrm{~V}_{\text {scan }} 50 \mathrm{mV} / \mathrm{s}$ ).

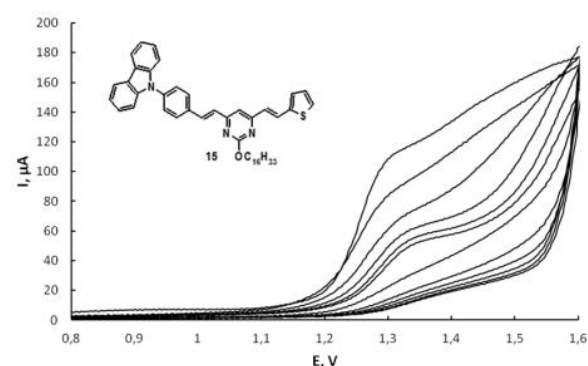

Figure 7. Cyclic voltammogram (10 cycles) of 15 (ITO electrode, $\mathrm{Et}_{4} \mathrm{NClO}_{4}, \mathrm{~V}_{\text {scan }} 50 \mathrm{mV} / \mathrm{s}$ ).

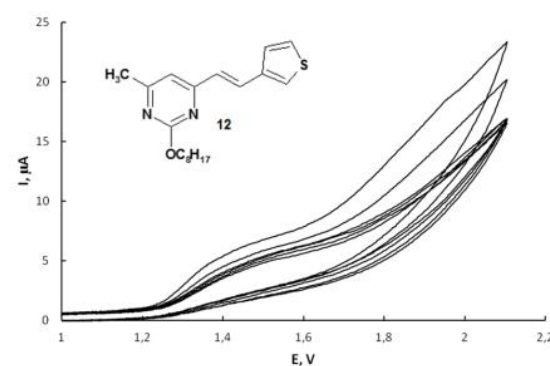

Figure 8. Cyclic voltammogram (10 cycles) of 12 (ITO electrode, $\mathrm{Et}_{4} \mathrm{NClO}_{4}, \mathrm{~V}_{\text {scan }} 50 \mathrm{mV} / \mathrm{s}$ ).

The pyrimidines $\mathbf{3}, \mathbf{9 - 1 1}, \mathbf{1 7 - 1 9}$, containing the carbazole and thiophene fragments with only one free 
electron rich position, easily form dimers, which subsequent polymerization proceeds scarcely (Figure 10-11) or does not occur at all. Here we present two cyclic voltammograms, obtained for compound 17, including 9ethyl-9H-carbazol-3-yl and thiophene-2-yl moieties (Figs. 9-10).

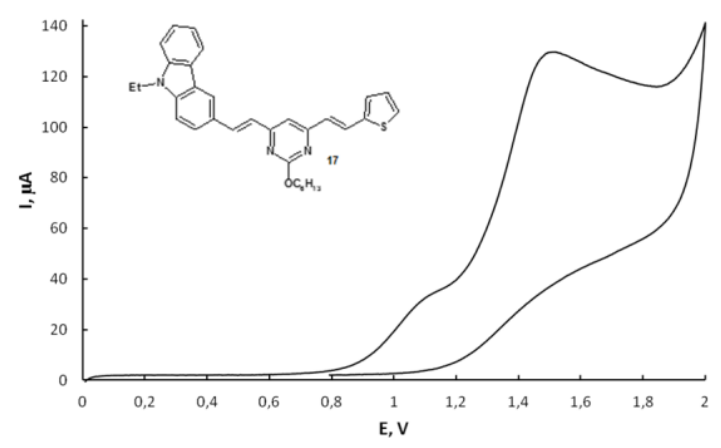

Figure 9. Cyclic voltammogram ( $1^{\text {st }}$ cycles) of 17 (ITO electrode, $\mathrm{Et}_{4} \mathrm{NClO}_{4}, \mathrm{~V}_{\text {scan }} 50$ $\mathrm{mV} / \mathrm{s})$.

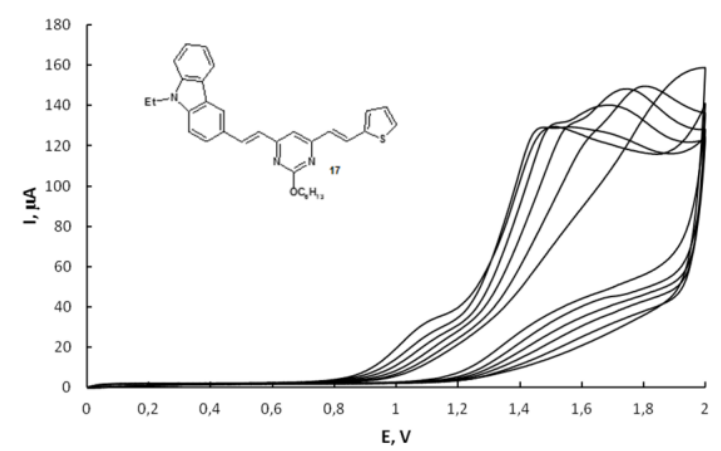

Figure 11. Cyclic voltammogram (10 cycles) of 17 (ITO electrode, $\mathrm{Et}_{4} \mathrm{NClO}_{4}, \mathrm{~V}_{\text {scan }} 50 \mathrm{mV} / \mathrm{s}$ ).

The analysis of cyclic voltammograms reveals that electrochemical oxidation of the pyrimidines, containing both carbazole and thiophene fragments, starts with a carbazole moiety oxidation to give an initial cation-radical (Scheme 2) as the first step. ${ }^{48-49}$ For compounds $\mathbf{2 , ~ 5 - 8}$ and 14-16 the value of the first oxidation potential $\left(E^{1}{ }_{o x}\right)$ lies in the interval 1.25-1.3 V. The priority oxidation of the carbazole unit is indirectly confirmed by the fact that the oxidation processes of pyrimidines 4,12 and 13, which structures include only a thiophene moiety as a polymerizable fragment, occurs at the much higher potential values $1.74-1.80 \mathrm{~V}$. As the next step radical cations formed in this way can combine with each other to form dimer dications ${ }^{48-49}$ or to combine with a neutral of carbazole containing pyrimidine (Scheme 2$)^{49}$ to form a dimer cation. The following elimination of two \one protons results in the formation of neutral dimers, capable of further oxidation. ${ }^{48-49}$ As a result, compounds 2, 5-8 and 14-16 have successfully undergone electrochemical oxidation and formed oligomeric thin films on the working electrode surfaces. It is fair to assume that the structure of thus generated oligomers present a backbone consisting of carbazole fragments, which nitrogen atoms are linked with styrene hands containing terminal 2,6-disubstituted pyrimidine moiety. The examples of such structures (7P and 8P) are shown in Figure 12.

The analysis of cyclic voltammograms obtained in the process of electrochemical oxidation of pyrimidines 17-19, including $N$-ethylcarbazole moiety, has shown that the oxidation of these compounds starts at the less positive potentials if compared with those of pyrimidines 2, 5-8 and 14-16, incorporating 4(carbazol-9-yl) phenyl moiety. This fact is a result of the less effective conjugation of a ( $\mathrm{N}$-ethylcarbazol-3$\mathrm{yl}$ )vinyl fragment with a central pyrimidine core. This is also confirmed by the absence of the long-wavelength absorption bands in the UV and fluorescence spectra of pyrimidines 17-19. The values of the redox potentials

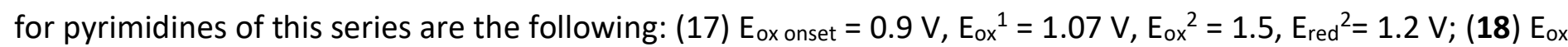
onset $=1.2 \mathrm{~V}, \mathrm{E}^{\mathrm{ox}}=1.6 ;(19) \mathrm{E}_{\mathrm{ox} \text { onset }}=0.95 \mathrm{~V}, \mathrm{E}_{\mathrm{ox}}{ }^{1}=1.15 \mathrm{~V}, \mathrm{E}_{\mathrm{ox}}{ }^{2}=1.6 \mathrm{~V}$. As in the previous series the first oxidation potentials $\left(E^{1}{ }_{\text {ox }}\right)$ correspond to the formation of the initial cation radicals. The following processes (Scheme 2) provide corresponding neutral dimers. The repeated potential scans of dimers have given rise to yellow thin films of these compounds (17P-19P), which composition differs from that of films 7P-8P-obtained by the electrochemical oxidation of compounds of the previous series and probably represents a dimer, including a pyrimidine cycles as a part of the conjugated backbone (Figure 12). 


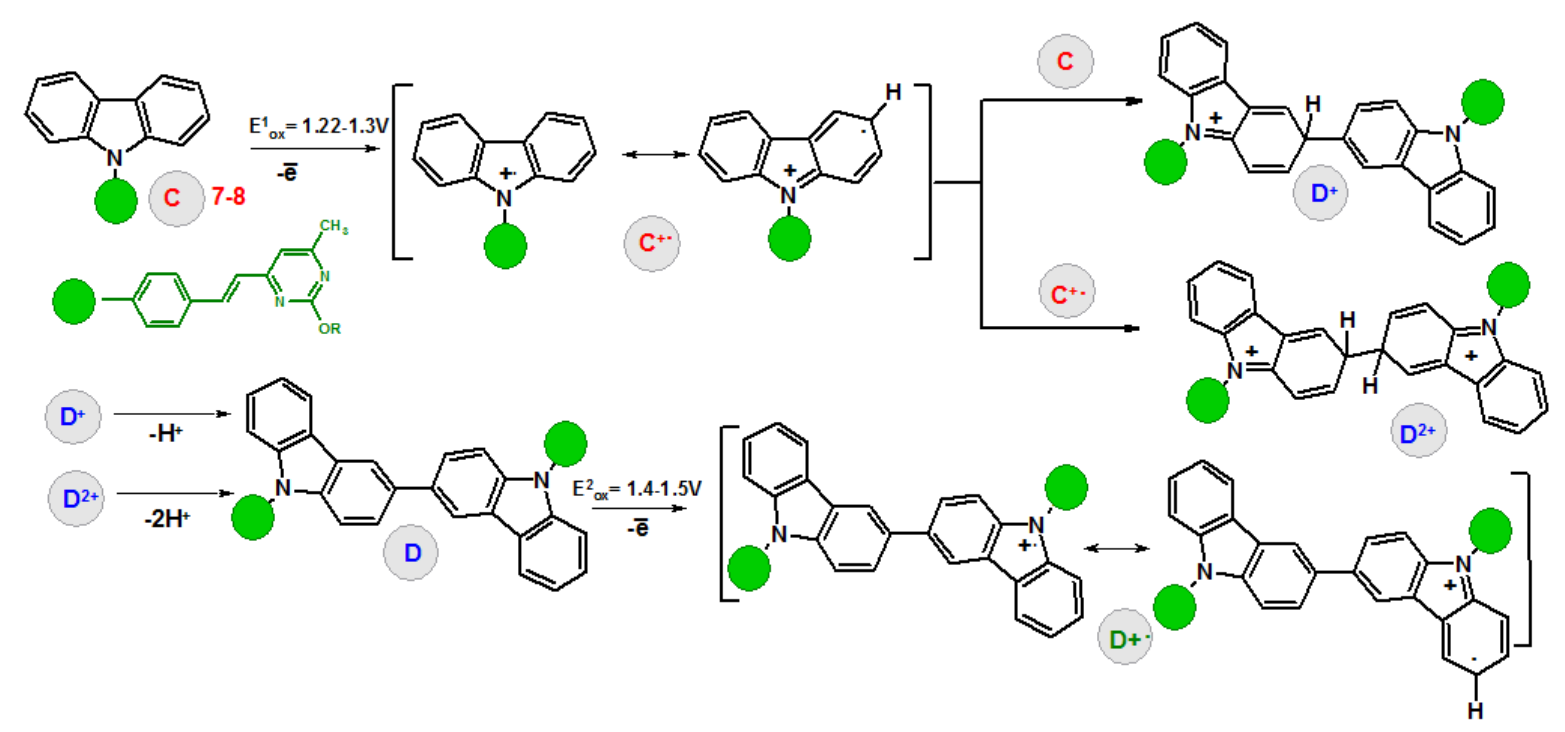

Scheme 2. The supposed scheme of electrochemical polymerization of carbazole-containing pyrimidines (pyrimidines 7-8 were used as an example).
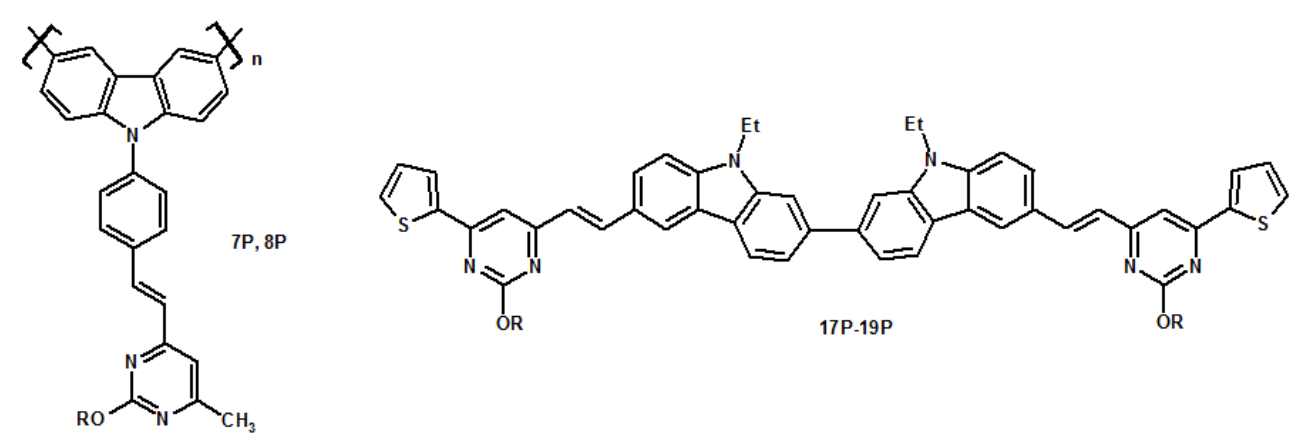

Figure 12. The supposed structure ofoligomers/dimers obtained by electrochemical oxidation of pyrimidines 7-8 and 17-19.

The electrochemical behavior of thus prepared thin films was studied with the help of cyclic voltammetry. Such important characteristics as the values of HOMO-LUMO ( $E_{\text {HOMO}} / E_{\text {LUMO }}$ ) and bandgap ( $E_{\mathbf{g}}{ }^{\text {elc }}$ ) energies were obtained on the basis of measured oxidation/reduction onset potentials using an equation $\mathrm{E}_{\text {Hомо } / \text { LUmо }}=\left[\left(\mathrm{E}_{\mathrm{ox} / \mathrm{red} \mathrm{vs} \mathrm{Ag} / \mathrm{AgCl}}\right)-4.50\right]^{50}$ (Table 2$)$.

Table 2. Electrochemical data of films obtained on the basis of the synthesized compounds

\begin{tabular}{cccccccccccc}
\hline Compound & $\mathbf{2}$ & $\mathbf{5}$ & $\mathbf{6}$ & $\mathbf{7}$ & $\mathbf{8}$ & $\mathbf{1 4}$ & $\mathbf{1 5}$ & $\mathbf{1 6}$ & $\mathbf{1 7}$ & $\mathbf{1 8}$ & $\mathbf{1 9}$ \\
\hline Eномо, $\mathrm{eV}$ & -5.61 & -5.54 & -5.58 & -5.67 & -5.64 & -5.53 & -5.62 & -5.60 & -5.50 & -5.57 & -5.43 \\
$\mathrm{E}_{\mathrm{LUMm}}, \mathrm{eV}$ & -4.37 & -4.15 & -4.14 & -4.31 & 4.37 & -4.13 & -4.14 & -4.18 & -3.85 & -3.60 & -4.19 \\
$\mathrm{E}_{\mathrm{g}}{ }^{\mathrm{Il}}, \mathrm{eV}$ & 1.24 & 1.39 & 1.44 & 1.36 & 1.27 & 1.40 & 1.48 & 1.42 & 1.85 & 1.96 & 1.24 \\
\hline
\end{tabular}




\section{Conclusions}

A set of novel asymmetrical chromophores of $D-\pi-A-\pi-D^{\prime}$ motif with a central electron deficient pyrimidine core Y-shaped was prepared using step-by-step condensations of 2-hydroxy-4,6-dimethylpyrimidine with arene carbaldehydes, including thiophene or carbazole units. The study of optical, electrochemical and electrophysical properties of thus prepared compounds has shown that these properties strongly depend on the mode in which a carbazole moiety is integrated into the chain of conjugation. All the prepared compounds have revealed strong fluorescent properties. Large Stokes shifts and broadband fluorescence inherent to these chromophores suggest their use as materials for luminescent solar collectors (LSCs). Electrochemical oxidation of all the prepared compounds has resulted in the formation of oligomer/polymer films on the electrode surfaces; electrochemical and energetic characteristics of the films were studied by cyclic voltammetry. Monomers including 4-(9H-carbazol-9-yl)phenyl units were found to have low values of optical ( $\left.\mathrm{E}_{\mathrm{g}}{ }^{\mathrm{pt}}\right)$ and electrochemical $\left(E_{\mathrm{g}}{ }^{\text {elc }}\right)$ bandgaps and the redshifted absorption and emission maxima. All the films prepared on the basis of these monomers also exhibit low values of electrochemical bandgaps $\left(E_{\mathrm{g}}\right.$ elc $\left.\sim 1.24-1.96 \mathrm{eV}\right)$; their $\mathrm{HOMO} / \mathrm{LUMO}$ energies of monomers lie within the $-5.43--5.61 \mathrm{eV}$ interval for HOMO and within - 3.6 - $4.37 \mathrm{eV}$ interval for LUMO. At the same time the monomers incorporating $N$-ethylcarbazol-3-yl fragment have been found to be oxidized easier than the monomers with 4-(9H-carbazol-9-yl)phenyl unit in their structures.

\section{Experimental Section}

General. All the required solvents were dried following the standard procedures. ${ }^{1} \mathrm{H}(300 \mathrm{MHz}),{ }^{13} \mathrm{C}(75 \mathrm{MHz})$ NMR spectra were registered on a Varian Mercury plus-300 spectrometer in $\mathrm{CDCl}_{3}$ with hexamethyldisiloxane (0.055 ppm) as an internal standard. Mass spectra were recorded on an Agilent Technologies 6890N/5975B instrument (EI, $70 \mathrm{eV})$. The elemental analysis was carried out using CHNS-932 LECO Corp analyzer. UV-Vis absorption spectra were recorded in $10 \mathrm{~mm}$ cuvettes on a Shimadzu UV-2600 spectrophotometer for $\mathrm{CHCl}_{3}$ solution of compounds. Fluorescence spectra were recorded on a Shimadzu RF-5301 PC spectrofluorophotometer: the excitation wavelength - $220 \mathrm{~nm}$, cuvette dimensions $10 \times 10 \mathrm{~mm}$, solvent $\mathrm{CHCl}_{3}$. Purity of compounds was tested by thin-layer chromatography using Sorbfil plates, visualized with UV light $(365 \mathrm{~nm})$ or iodine vapours. The mixtures were separated and the target products were purified by column chromatography on silica gel (Lancaster, Silica Gel 60, 0.060-0.2 mm). Electrochemical measurements were carried out on a potentiostat/galvanostat (ZRA Interface 1000), using a standard three-electrode cell with a ITO or carbon-pyroceramic working electrodes, a Pt wire counter electrode, and a $\mathrm{Ag} / \mathrm{Ag}+\mathrm{reference}$ electrode. The supporting electrolyte was $0.1 \mathrm{~mol} \mathrm{~L}^{-1}$ solution of $\mathrm{Et}_{4} \mathrm{NClO}_{4}$ in the acetonitrile-dichloromethane (1:1) mixture. The potential scan rate $\left(\mathrm{V}_{\text {scan }}\right)$ was $50 \mathrm{mV} / \mathrm{s}$. 2-Thiophenecarboxaldehyde, 3thiophenecarboxaldehyde, 2-ethylhexyl bromide and 1-bromohexadecane were purchased from Alfa Aesar. Synthesis of 2-hydroxy-4,6-dimethylpyrimidine hydrochloride 1 was carried out by the previously described procedure. $^{31}$

General method of synthesis of 2-hydroxypyrimidines 2-6. ${ }^{20}$ An equimolar mixture (0.0125 mol) of 2hydroxypyrimidines 1-2 and a corresponding arylcarboxaldehyde in $80 \mathrm{ml}$ of ethanol was stirred for about 15 min and then treated with $2.5 \mathrm{~mL}$ of $\mathrm{HCl}(\mathrm{cc})$. The obtained reaction mixture was heated under reflux for $6 \mathrm{~h}$ to give the corresponding hydrochlorides as red solids, which were then neutralized by $10 \%$ aqueous-alcoholic 
solution of carbonate of potassium. The resulting products (yellow solids) were filtered off, washed by hot ethanol and dried in the air.

General method of 2-hydroxypyrimidines alkylation (synthesis of 7-19). ${ }^{20}$ The equimolar mixture (0.9 mmol) of a corresponding 2-hydroxypyrimidine (2 - 6) $(0.9 \mathrm{mmol}, 0.2 \mathrm{~g})$ and bromoalkane in $30 \mathrm{ml}$ of DMF was heated and stirred under reflux for $5 \mathrm{~h}$ in presence of $9 \mathrm{mmol}$ of $\mathrm{K}_{2} \mathrm{CO}_{3}(1,13 \mathrm{~g})$, then cooled and poured into ice. The resulted product (usually a yellow precipitate) was filtrated off and dry in the air. The precipitate was purified by column chromatography (eluent $\mathrm{CH}_{2} \mathrm{Cl}_{2}: \mathrm{C}_{6} \mathrm{H}_{14}, 1: 1$ ).

General method of synthesis of 2-alkoxypyrimidines 14-19 (way 2). An equimolar mixture (0.0125 mol) of 2alkoxy-6-(2-arylvinyl)-4-methylpyrimidines 7-13 and a corresponding arylcarboxaldehyde in $80 \mathrm{~mL}$ of ethanol was treated with $2.5 \mathrm{~mL}$ of $\mathrm{HCl}(\mathrm{cc})$. The obtained reaction mixture was heated under reflux for $6 \mathrm{~h}$ to give the corresponding hydrochlorides as red solids, which were then neutralized by $10 \%$ aqueous-alcoholic solution of carbonate of potassium. The resulting products (yellow solids) were filtered off, washed by hot ethanol and dried in the air.

4-\{2-[4-(9H-Carbazol-9-yl)phenyl]ethenyl\}-2-hydroxy-6-methylpyrimidine (2). Yellow powder, yield 60\%, 2.8 g, mp $260{ }^{\circ} \mathrm{C} .{ }^{1} \mathrm{H}$ NMR: $\delta_{\mathrm{H}} 2.40\left(3 \mathrm{H}, \mathrm{s}, \mathrm{CH}_{3}\right), 6.64\left(1 \mathrm{H}, \mathrm{s}\right.$, pyrimidine), $7.08\left(2 \mathrm{H}, \mathrm{t},{ }^{3} \mathrm{~J}_{\mathrm{HH}} 8.7 \mathrm{~Hz}\right.$, carbazole), 7.09 $\left(1 \mathrm{H}, \mathrm{d}, 3^{3} \mathrm{~J}_{H H} 16.7 \mathrm{~Hz}, \mathrm{CH}=\right), 7.40\left(2 \mathrm{H}, \mathrm{t}, 3^{3} \mathrm{JHH} 6.0 \mathrm{~Hz}\right.$, carbazole), $7.50(4 \mathrm{H}: 2 \mathrm{H}$, carbazole, $1 \mathrm{H}, \mathrm{CH}=, 1 \mathrm{H}, \mathrm{OH}, \mathrm{m}), 7.84$ $\left(2 \mathrm{H}, \mathrm{d},{ }^{3} \mathrm{~J}_{H H} 8.7 \mathrm{~Hz}, \mathrm{Ar}\right), 8.07\left(2 \mathrm{H}, \mathrm{d},{ }^{3} \mathrm{~J}_{H H} 7.5 \mathrm{~Hz}\right.$, carbazole), $8.14\left(2 \mathrm{H}, \mathrm{d},{ }^{3} J_{H H} 7.8 \mathrm{~Hz}, \mathrm{Ar}\right)$. Anal. Calcd for $\mathrm{C}_{25} \mathrm{H}_{19} \mathrm{~N}_{3} \mathrm{O}$ (377.44): C, 79.55; $\mathrm{H}, 5.07 ; \mathrm{N}, 11.13 \%$. Found: $\mathrm{C}, 79.51 ; \mathrm{H}, 5.01 ; \mathrm{N}, 11.02 \%$.

2-Hydroxy-4-methyl-6-[2-(thiophen-2-yl)ethenyl]pyrimidine (3). Yellow powder, yield 90\%, $2.9 \mathrm{~g}, \mathrm{mp}>260{ }^{\circ} \mathrm{C}$. ${ }^{1} \mathrm{H}$ NMR: $\delta_{\mathrm{H}} 2.40\left(3 \mathrm{H}, \mathrm{s}, \mathrm{CH}_{3}\right), 6.43(1 \mathrm{H}, \mathrm{s}, \mathrm{OH}), 6.69,6.74\left(1 \mathrm{H}, \mathrm{d},{ }^{3} \mathrm{~J}_{\mathrm{HH}} 15.6 \mathrm{~Hz}, \mathrm{CH}=\right), 7.09\left(1 \mathrm{H}, \mathrm{t},{ }^{3} \mathrm{~J}_{\mathrm{HH}} 3.6 \mathrm{~Hz}\right.$, thiophene), $7.27\left(1 \mathrm{H}, \mathrm{s}\right.$, pyrimidine), 7.34, $7.35\left(1 \mathrm{H}, \mathrm{d},{ }^{3} J_{H H} 3.3 \mathrm{~Hz}\right.$, thiophene), $7.47\left(1 \mathrm{H}, \mathrm{d},{ }^{3} J_{H H} 5.1 \mathrm{~Hz}\right.$, thiophene), 8.09, $8.14\left(1 \mathrm{H}, \mathrm{d},{ }^{3} J_{H H} 15.9 \mathrm{~Hz}, \mathrm{CH}=\right) .{ }^{13} \mathrm{C} N M R: \delta_{C} 18.9,88.2,119.9,128.9,131.8,131.9,133.9$, 143.3, 152.7, 155.9, 164.9. Anal. Calcd for $\mathrm{C}_{11} \mathrm{H}_{10} \mathrm{~N}_{2} \mathrm{OS}$ (218.27): C, 50.53; H,4.62; N, 12.83; S, 14.69\%. Found: C, $50.48 ; H, 4.56 ; \mathrm{N}, 12.72 ; \mathrm{S}, 14.56 \%$.

2-Hydroxy-4-methyl-6-[2-(thiophen-3-yl)ethenyl]pyrimidine (4). Yellow powder, yield 57\%, $3.3 \mathrm{~g}, \mathrm{mp}>300{ }^{0} \mathrm{C}$. ${ }^{1} \mathrm{H}$ NMR: $\delta_{\mathrm{H}} 2.43\left(3 \mathrm{H}, \mathrm{s}, \mathrm{CH}_{3}\right), 6.68\left(1 \mathrm{H}, \mathrm{d},{ }^{3} \mathrm{~J}_{H H} 15.6 \mathrm{~Hz}, \mathrm{CH}=\right), 6.80(1 \mathrm{H}, \mathrm{s}$, pyrimidine $), 7.04\left(1 \mathrm{H}, \mathrm{d},{ }^{3} \mathrm{JHH}^{3} 3.9 \mathrm{~Hz}\right.$, thiophene), $7.22\left(1 \mathrm{H}, \mathrm{d},{ }^{3} \mathrm{~J}_{H H} 3.3 \mathrm{~Hz}\right.$, thiophene), $7.31\left(1 \mathrm{H}, \mathrm{s}\right.$, thiophene), $7.77\left(1 \mathrm{H}, \mathrm{d},{ }^{3} \mathrm{~J}_{H H} 15.6 \mathrm{~Hz}, \mathrm{CH}=\right)$. Anal. Calcd for $\mathrm{C}_{11} \mathrm{H}_{10} \mathrm{~N}_{2} \mathrm{OS}$ (218.27): C, 50.53; H, 4.62; N, 12.83; S, 14.69\%. Found: C, 50.47; H, 4.54; N, 12.70; S, $14.55 \%$.

4-\{2-[4-(9H-Carbazol-9-yl)phenyl]ethenyl\}-2-hydroxy-6-[2-(thiophen-2-yl)ethenyl]pyrimidine (5). Yellow powder, yield 54\%, $3.4 \mathrm{~g}, \mathrm{mp}>300{ }^{\circ} \mathrm{C} .{ }^{1} \mathrm{H}$ NMR: $\delta_{\mathrm{H}} 7.21(6 \mathrm{H}: 1 \mathrm{H}$, thiophene, $2 \mathrm{H}$, carbazole, $1 \mathrm{H}, \mathrm{pyrimidine}, 1 \mathrm{H}$, $\mathrm{CH}=, 1 \mathrm{H}, \mathrm{CH}=, \mathrm{m}), 7.41(5 \mathrm{H}: 2 \mathrm{H}$, carbazole, $1 \mathrm{H}, \mathrm{CH}=, 1 \mathrm{H}, \mathrm{CH}=, 1 \mathrm{H}, \mathrm{OH}, \mathrm{m}), 7.49\left(2 \mathrm{H}, \mathrm{d}, 3_{H H} 7.2 \mathrm{~Hz}\right.$, carbazole), $7.52\left(1 \mathrm{H}, \mathrm{d},{ }^{3} \mathrm{~J}_{\mathrm{HH}} 3.3 \mathrm{~Hz}\right.$, thiophene), $7.69\left(1 \mathrm{H}, \mathrm{d},{ }^{3} \mathrm{~J}_{H H} 3.3 \mathrm{~Hz}\right.$, thiophene), $7.86\left(2 \mathrm{H}, \mathrm{d},{ }^{3} \mathrm{~J}_{H H} 8.4 \mathrm{~Hz}, \mathrm{Ar}\right), 8.07(2 \mathrm{H}, \mathrm{d}$, ${ }^{3} J_{H H} 7.5 \mathrm{~Hz}$, carbazole), $8.14\left(2 \mathrm{H}, \mathrm{d}, 3^{3} \mathrm{~J}_{H H} 8.7 \mathrm{~Hz}, \mathrm{Ar}\right)$. Anal. Calcd for $\mathrm{C}_{30} \mathrm{H}_{21} \mathrm{~N}_{3} \mathrm{OS}$ (471.57): C, 76.41; H, 4.49; N, 8.91; S, 6.80\%. Found: C, 76.35; H, 4.42; N, 8.82; S, 6.67\%.

4-\{2-[4-(9H-Carbazol-9-yl)phenyl]ethenyl\}-2-hydroxy-6-[2-(thiophen-3-yl)ethenyl]pyrimidine (6). Yellow powder, yield $60 \%, 1.4 \mathrm{~g}, \mathrm{mp}>300{ }^{\circ} \mathrm{C} .{ }^{1} \mathrm{H}$ NMR: $\delta_{\mathrm{H}} 7.23(6 \mathrm{H}$ : $1 \mathrm{H}$, thiophene, $2 \mathrm{H}$, carbazole, $1 \mathrm{H}$, pyrimidine, $1 \mathrm{H}$, $\mathrm{CH}=, 1 \mathrm{H}, \mathrm{CH}=, \mathrm{m}), 7.41(5 \mathrm{H}: 2 \mathrm{H}$, carbazole, $1 \mathrm{H}, \mathrm{CH}=, 1 \mathrm{H}, \mathrm{CH}=, 1 \mathrm{H}, \mathrm{OH}, \mathrm{m}), 7.49\left(2 \mathrm{H}, \mathrm{d}, 3^{3} \mathrm{HH} 7.2 \mathrm{~Hz}\right.$, carbazole), $7.51\left(1 \mathrm{H}, \mathrm{d},{ }^{3} \mathrm{~J}_{H H} 3.3 \mathrm{~Hz}\right.$, thiophene), $7.69\left(1 \mathrm{H}, \mathrm{d},{ }^{3} \mathrm{~J}_{H H} 3.3 \mathrm{~Hz}\right.$, thiophene), $7.86\left(2 \mathrm{H}, \mathrm{d},{ }^{3} \mathrm{~J}_{H H} 8.4 \mathrm{~Hz}, \mathrm{Ar}\right), 8.06(2 \mathrm{H}$, d, ${ }^{3} \mathrm{~J}_{\mathrm{HH}} 7.5 \mathrm{~Hz}$, carbazole), $8.14\left(2 \mathrm{H}, \mathrm{d},{ }^{3} \mathrm{~J}_{\mathrm{HH}} 8.7 \mathrm{~Hz}, \mathrm{Ar}\right)$. Anal. Calcd for $\mathrm{C}_{30} \mathrm{H}_{21} \mathrm{~N}_{3} \mathrm{OS}$ (471.57): C, 76.41; H, 4.49; N, 8.91; S, 6.80\%. Found: C, 76.37; H, 4.39; N, 8.85; S, 6.69\%.

4-\{[4-(9H-Carbazol-9-yl)phenyl]ethenyl\}-6-methyl-2-octyloxypyrimidine (7). Yellow viscous substance, yield 65\%, 0.28 g. ${ }^{1} \mathrm{H}$ NMR: $\delta_{\mathrm{H}} 0.87\left(3 \mathrm{H}, \mathrm{t},{ }^{3} \mathrm{~J}_{\mathrm{HH}} 6.6 \mathrm{~Hz}, \mathrm{CH}_{3}\right), 1.29\left(12 \mathrm{H}, \mathrm{m}, 6 \mathrm{CH}_{2}\right), 2.40\left(3 \mathrm{H}, \mathrm{s}, \mathrm{CH}_{3}\right), 4.32\left(2 \mathrm{H}, \mathrm{t},{ }^{3} J_{H H} 6.6\right.$ $\left.\mathrm{Hz}, \mathrm{OCH}_{2}\right), 6.64\left(1 \mathrm{H}, \mathrm{s}\right.$, pyrimidine), $7.08\left(2 \mathrm{H}, \mathrm{t},{ }^{3} \mathrm{~J}_{H H} 8.7 \mathrm{~Hz}\right.$, carbazole), $7.09\left(1 \mathrm{H}, \mathrm{d},{ }^{3} \mathrm{JHH} 16.7 \mathrm{~Hz}, \mathrm{CH}=\right), 7.40(2 \mathrm{H}$, 
t, ${ }^{3} J_{H H} 6.0 \mathrm{~Hz}$, carbazole), $7.50(3 \mathrm{H}: 2 \mathrm{H}$ carbazole, $1 \mathrm{H}, \mathrm{CH}=\mathrm{m}), 7.84\left(2 \mathrm{H}, \mathrm{d},{ }^{3} \mathrm{~J}_{H H} 8.7 \mathrm{~Hz}, \mathrm{Ar}\right), 8.07\left(2 \mathrm{H}, \mathrm{d},{ }^{3} J_{H H} 7.5\right.$ $\mathrm{Hz}$, carbazole), $8.14\left(2 \mathrm{H}, \mathrm{d},{ }^{3} \mathrm{~J}_{\mathrm{HH}} 7.8 \mathrm{~Hz}, \mathrm{Ar}\right)$. Anal. Calcd for $\mathrm{C}_{33} \mathrm{H}_{35} \mathrm{~N}_{3} \mathrm{O}$ (489.65): C, 80.95; $\mathrm{H}, 7.20 ; \mathrm{N}, 8.58 \%$. Found: $C, 80.89 ; \mathrm{H}, 7.12 ; \mathrm{N}, 8.49 \%$.

4-\{[4-(9H-Carbazol-9-yl)phenyl]ethenyl\}-2-hexadecyloxy-6-methylpyrimidine (8). Yellow viscous substance, yield 61\%, $0.33 \mathrm{~g} .{ }^{1} \mathrm{H}$ NMR: $\delta_{\mathrm{H}} 0.88\left(3 \mathrm{H}, \mathrm{t},{ }^{3} \mathrm{~J}_{H H} 6.3 \mathrm{~Hz}, \mathrm{CH}_{3}\right), 1.24\left(28 \mathrm{H}, \mathrm{m}, 14 \mathrm{CH}_{2}\right), 2.40\left(3 \mathrm{H}, \mathrm{s}, \mathrm{CH}_{3}\right), 4.20(2 \mathrm{H}, \mathrm{t}$, $\left.{ }^{3} J_{H H} 6.6 \mathrm{~Hz}, \mathrm{OCH}_{2}\right), 6.64\left(1 \mathrm{H}, \mathrm{s}\right.$, pyrimidine) $7.08\left(2 \mathrm{H}, \mathrm{t},{ }^{3} J_{H H} 8.7 \mathrm{~Hz}\right.$, carbazole), $7.09\left(1 \mathrm{H}, \mathrm{d},{ }^{3} J_{H H} 16.7 \mathrm{~Hz}, \mathrm{CH}=\right)$, $7.40\left(2 \mathrm{H}, \mathrm{t}, 3^{3} \mathrm{JHH} 6.0 \mathrm{~Hz}\right.$, carbazole), $7.50(3 \mathrm{H}: 2 \mathrm{H}$, carbazole, $1 \mathrm{H}, \mathrm{CH}=, \mathrm{m}), 7.84\left(2 \mathrm{H}, \mathrm{d},{ }^{3} \mathrm{~J}_{H H} 8.7 \mathrm{~Hz}, \mathrm{Ar}\right), 8.07(2 \mathrm{H}$, d, ${ }^{3} \mathrm{~J}_{H H} 7.5 \mathrm{~Hz}$, carbazole), $8.14\left(2 \mathrm{H}, \mathrm{d},{ }^{3} \mathrm{~J}_{H H} 7.8 \mathrm{~Hz}, \mathrm{Ar}\right)$. Anal. Calcd for $\mathrm{C}_{41} \mathrm{H}_{51} \mathrm{~N}_{3} \mathrm{O}$ (601.86): C, 81.82; $\mathrm{H}, 8.54 ; \mathrm{N}$, 6.98\%. Found: $C, 81.75 ; H, 8.47 ; \mathrm{N}, 6.85 \%$.

2-Hexyloxy-4-methyl-6-[2-(thiophen-2-yl)ethenyl]pyrimidine (9). Yellow viscous substance, yield $45 \%, 0.12 \mathrm{~g}$. ${ }^{1} \mathrm{H}$ NMR: $\delta_{\mathrm{H}} 0.89\left(3 \mathrm{H}, \mathrm{t},{ }^{3} \mathrm{~J}_{\mathrm{HH}} 6.9 \mathrm{~Hz}, \mathrm{CH}_{3}\right), 1.34\left(4 \mathrm{H}, \mathrm{m}, 2 \mathrm{CH}_{2}\right), 1.55\left(2 \mathrm{H}, \mathrm{m}, \mathrm{OCH}_{2} \mathrm{CH}_{2} \mathrm{CH}_{2} \mathrm{C}\right), 1.82(2 \mathrm{H}, \mathrm{m}$, $\left.\mathrm{OCH}_{2} \underline{\mathrm{CH}_{2}} \mathrm{C}\right), 2.43\left(3 \mathrm{H}, \mathrm{s}, \mathrm{CH}_{3}\right), 4.37\left(2 \mathrm{H}, \mathrm{t},{ }^{3} \mathrm{~J}_{H H} 6.6 \mathrm{~Hz}, \mathrm{OCH}_{2}\right), 6.76,6.81\left(1 \mathrm{H}, \mathrm{d}, 3^{3} \mathrm{JHH}_{H} 15.3 \mathrm{~Hz}, \mathrm{CH}=\right), 7.05(1 \mathrm{H}, \mathrm{t}$, ${ }^{3} J_{H H} 4,8 \mathrm{~Hz}$, thiophene), $7.22\left(1 \mathrm{H}, \mathrm{s}\right.$, pyrimidine), 7.30, $7.32\left(1 \mathrm{H}, \mathrm{d},{ }^{3} \mathrm{~J}_{H H} 4,2 \mathrm{~Hz}\right.$, thiophene), $7.52\left(1 \mathrm{H}, \mathrm{d},{ }^{3} \mathrm{~J}_{H H} 5.4\right.$ $\mathrm{Hz}$, thiophene), 8.01, 8.06 (1H, d, $\left.{ }^{3} J_{H H} 15.6 \mathrm{~Hz}, \mathrm{CH}=\right) .{ }^{13} \mathrm{C} N M R: \delta_{c} 14.1,21.9,22.7,25.7,29.2,31.5,66.8,109.2$, 123.4, 124.2, 125.9, 129.5, 129.9, 142.8, 162.8, 166.4, 168.6. Anal. Calcd for $\mathrm{C}_{17} \mathrm{H}_{22} \mathrm{~N}_{2} \mathrm{OS}(302.43): \mathrm{C}, 67.51 ; \mathrm{H}$, 7.33; N, 9.26; S, 10.60\%. Found: C, 67.44; H, 7.26; N, 9.17; S, $10.46 \%$.

2-[(2-Ethylhexyl)oxy]-4-methyl-6-[2-(thiophen-2-yl)ethenyl]pyrimidine (10). Yellow viscous substance, yield 55\%, 0.16 g. ${ }^{1} \mathrm{H}$ NMR: $\delta_{\mathrm{H}} 0.94\left(6 \mathrm{H}, \mathrm{m}, 2 \mathrm{CH}_{3}\right), 1.32\left(8 \mathrm{H}, \mathrm{m}, 4 \mathrm{CH}_{2}\right), 1.59\left(1 \mathrm{H}, \mathrm{m}, \mathrm{OCH}_{2} \mathrm{CHC}\right), 2.43\left(3 \mathrm{H}, \mathrm{s}, \mathrm{CH}_{3}\right), 4.35$ $\left(2 \mathrm{H}, \mathrm{d},{ }^{3} \mathrm{~J}_{H H} 6.6 \mathrm{~Hz}, \mathrm{OCH}_{2}\right), 6.78,6.83\left(1 \mathrm{H}, \mathrm{d},{ }^{3} \mathrm{~J}_{H H} 15.3 \mathrm{~Hz}, \mathrm{CH}=\right), 7.05\left(1 \mathrm{H}, \mathrm{t},{ }^{3} J_{H H} 4.5 \mathrm{~Hz}\right.$, thiophene), $7.23(1 \mathrm{H}, \mathrm{s}$, pyrimidine), $7.32\left(1 \mathrm{H}, \mathrm{d},{ }^{3} J_{H H} 4.5 \mathrm{~Hz}\right.$, thiophene), $7.53\left(1 \mathrm{H}, \mathrm{d},{ }^{3} J_{H H} 3.6 \mathrm{~Hz}\right.$, thiophene), $7.99,8.04\left(1 \mathrm{H}, \mathrm{d},{ }^{3} J_{H H} 15.6\right.$ $\mathrm{Hz}, \mathrm{CH}=) .{ }^{13} \mathrm{C}$ NMR: $\delta_{c} 10.8,14.0,21.9,22.9,23.9,28.8,29.9,38.5,71.4,109.3,123.4,124.2,125.9,129.4$, 129.9, 142.9, 162.5, 164.4, 168.3. Anal. Calcd for $\mathrm{C}_{19} \mathrm{H}_{26} \mathrm{~N}_{2} \mathrm{OS}$ (330.49): C, 69.05; H, 7.93; N, 8.48; S, 9.70\%. Found: C, 68.97; H, 7.85; N, 8.35; S, 9.56\%.

2-Hexadecyloxy-4-methyl-6-[2-(thiophen-2-yl)ethenyl]pyrimidine (11). Yellow powder, yield 55\%, $0.22 \mathrm{~g}, \mathrm{mp}$ 62-63 ${ }^{0} \mathrm{C} .{ }^{1} \mathrm{H}$ NMR: $\delta_{\mathrm{H}} 0.86\left(3 \mathrm{H}, \mathrm{t},{ }^{3} \mathrm{JHH}^{1} 5.1 \mathrm{~Hz},{ }^{3} \mathrm{JHH}^{2} 6.9 \mathrm{~Hz}, \mathrm{CH}_{3}\right), 1.24\left(24 \mathrm{H}, \mathrm{m}, 12 \mathrm{CH}_{2}\right), 1.48(2 \mathrm{H}, \mathrm{m}$, $\left.\mathrm{OCH}_{2} \mathrm{CH}_{2} \mathrm{CH}_{2} \mathrm{C}\right), 1.81\left(2 \mathrm{H}, \mathrm{m}, \mathrm{OCH}_{2} \underline{\mathrm{CH}}_{2} \mathrm{C}\right), 2.43\left(3 \mathrm{H}, \mathrm{s}, \mathrm{CH}_{3}\right), 4.36\left(2 \mathrm{H}, \mathrm{t},{ }^{3} \mathrm{~J}_{H H} 6.7 \mathrm{~Hz}, \mathrm{OCH}_{2}\right), 6.71,6.76\left(1 \mathrm{H}, \mathrm{d}, 3^{3} \mathrm{JHH}\right.$ $15.3 \mathrm{~Hz}, \mathrm{CH}=), 7.04\left(1 \mathrm{H}, \mathrm{t},{ }^{3} J_{H H} 4.2 \mathrm{~Hz}\right.$, thiophene), $7.21,7.22\left(1 \mathrm{H}, \mathrm{d},{ }^{3} J_{H H} 3.6 \mathrm{~Hz}\right.$, thiophene), $7.23(1 \mathrm{H}, \mathrm{s}$, pyrimidine), 7.30, $7.31\left(1 \mathrm{H}, \mathrm{d},{ }^{3} J_{H H} 5.1 \mathrm{~Hz}\right.$, thiophene), 7.98, $8.03\left(1 \mathrm{H}, \mathrm{d},{ }^{3} J_{H H} 15.3 \mathrm{~Hz}, \mathrm{CH}=\right) .{ }^{13} \mathrm{C} N M R: \delta_{C} 14.3$, 21.9, 22.9, 25.7, 28.3, 29.2, 29.5, 29.7, 29.8, 29.9, 30.3, 30.4, 31.5, 66.9, 109.3, 123.4, 124.3, 125.7, 129.5, 129.8, 142.8, 162.9, 166.6, 168.7. Anal. Calcd for $\mathrm{C}_{27} \mathrm{H}_{42} \mathrm{~N}_{2} \mathrm{OS}$ (442.70): C, 73.25; H, 9.56; N, 6.33; S, 7.24\%. Found: C, 73.19; H, 9.49; N, 6.21; S, 7.09\%.

4-Methyl-2-octyloxy-6-[2-(thiophen-3-yl)ethenyl]pyrimidine (12). Yellow viscous substance, yield $61 \%, 0.11 \mathrm{~g}$. ${ }^{1} \mathrm{H} N M R: \delta_{H} 0.87\left(3 \mathrm{H}, \mathrm{t},{ }^{3} \mathrm{~J}_{H H} 6.6 \mathrm{~Hz}, \mathrm{CH}_{3}\right), 1.29\left(12 \mathrm{H}, \mathrm{m}, 6 \mathrm{CH}_{2}\right), 2.44\left(3 \mathrm{H}, \mathrm{s}, \mathrm{CH}_{3}\right), 4.32\left(2 \mathrm{H}, \mathrm{t},{ }^{3} \mathrm{~J}_{\mathrm{HH}} 6.6 \mathrm{~Hz}_{2}, \mathrm{OCH}_{2}\right)$, $6.68\left(1 \mathrm{H}, \mathrm{d},{ }^{3} J_{H H} 15.6 \mathrm{~Hz}, \mathrm{CH}=\right), 6.80\left(1 \mathrm{H}, \mathrm{s}\right.$, pyrimidine), $7.04\left(1 \mathrm{H}, \mathrm{d},{ }^{3} \mathrm{~J}_{H H} 3.9 \mathrm{~Hz}\right.$, thiophene), $7.22\left(1 \mathrm{H}, \mathrm{d},{ }^{3} J_{H H} 3.3\right.$ $\mathrm{Hz}$, thiophene), $7.31\left(1 \mathrm{H}, \mathrm{s}\right.$, thiophene), $7.77\left(1 \mathrm{H}, \mathrm{d},{ }^{3} \mathrm{~J}_{\mathrm{HH}} 15.6 \mathrm{~Hz}, \mathrm{CH}=\right)$. Anal. Calcd for $\mathrm{C}_{19} \mathrm{H}_{26} \mathrm{~N}_{2} \mathrm{OS}$ (330.49): C, 69.05; H, 7.93; N, 8.48; S, 9.70\%. Found: C, 68.98; H, 7.87; N, 7.37; S, 9.55\%.

2-Hexadecyloxy-4-methyl-6-[2-(thiophen-3-yl)ethenyl]pyrimidine (13). Yellow viscous substance, yield 63\%, 0.25 g. ${ }^{1} \mathrm{H}$ NMR: $\delta_{\mathrm{H}} 0.87\left(3 \mathrm{H}, \mathrm{t},{ }^{3} \mathrm{~J}_{H H} 6.3 \mathrm{~Hz}, \mathrm{CH}_{3}\right), 1.25\left(28 \mathrm{H}, \mathrm{m}, 14 \mathrm{CH}_{2}\right), 2.43\left(3 \mathrm{H}, \mathrm{s}, \mathrm{CH}_{3}\right), 4.22\left(2 \mathrm{H}, \mathrm{t}, 3^{3} \mathrm{JHH} 6.6 \mathrm{~Hz}\right.$, $\left.\mathrm{OCH}_{2}\right), 6.68\left(1 \mathrm{H}, \mathrm{d},{ }^{3} \mathrm{~J}_{H H} 15.6 \mathrm{~Hz}, \mathrm{CH}=\right), 6.80\left(1 \mathrm{H}, \mathrm{s}\right.$, pyrimidine), $7.04\left(1 \mathrm{H}, \mathrm{d},{ }^{3} \mathrm{~J}_{H H} 3.9 \mathrm{~Hz}\right.$, thiophene), $7.22(1 \mathrm{H}, \mathrm{d}$, ${ }^{3} J_{H H} 3.3 \mathrm{~Hz}$, thiophene), $7.31\left(1 \mathrm{H}, \mathrm{s}\right.$, thiophene), $7.77\left(1 \mathrm{H}, \mathrm{d},{ }^{3} \mathrm{~J}_{H H} 15.6 \mathrm{~Hz}, \mathrm{CH}=\right)$. Anal. Calcd for $\mathrm{C}_{27} \mathrm{H}_{42} \mathrm{~N}_{2} \mathrm{OS}$ (442.70): C, 73.25; H, 9.56; N, 6.33; S, 7.24\%. Found: C, 73.18; H, 9.48; N, 6.22; S, 7.09\%.

4-\{[4-(9H-Carbazol-9-yl)phenyl]ethenyl\}-2-octyloxy-6-[2-(thiophen-2-yl)ethenyl]pyrimidine (14). Yellow powder, yield $60 \%, 0.31 \mathrm{~g}$, mp $113-115^{0} \mathrm{C} .{ }^{1} \mathrm{H}$ NMR: $\delta_{\mathrm{H}} 0.88\left(3 \mathrm{H}, \mathrm{t},{ }^{3} \mathrm{~J}_{H H} 6.6 \mathrm{~Hz}, \mathrm{CH}_{3}\right), 1.30\left(12 \mathrm{H}, \mathrm{m}, 6 \mathrm{CH}_{2}\right), 4.21$ $\left(2 \mathrm{H}, \mathrm{t},{ }^{3} \mathrm{JHH}_{\mathrm{H}} 6.6 \mathrm{~Hz}, \mathrm{OCH}_{2}\right), 7.21(6 \mathrm{H}: 1 \mathrm{H}$, thiophene, $2 \mathrm{H}$, carbazole, $1 \mathrm{H}$, pyrimidine, $1 \mathrm{H}, \mathrm{CH}=, 1 \mathrm{H}, \mathrm{CH}=, \mathrm{m}), 7.41$ 
(4H: $2 \mathrm{H}$, carbazole, $1 \mathrm{H}, \mathrm{CH}=, \mathrm{CH}=, \mathrm{m}), 7.49\left(2 \mathrm{H}, \mathrm{d},{ }^{3} \mathrm{~J}_{H H} 7.2 \mathrm{~Hz}\right.$, carbazole), $7.52\left(1 \mathrm{H}, \mathrm{d},{ }^{3} J_{H H} 3.3 \mathrm{~Hz}\right.$, thiophene), $7.69\left(1 \mathrm{H}, \mathrm{d},{ }^{3} \mathrm{~J}_{\mathrm{HH}} 3.3 \mathrm{~Hz}\right.$, thiophene), $7.86\left(2 \mathrm{H}, \mathrm{d},{ }^{3} \mathrm{~J}_{H H} 8.4 \mathrm{~Hz}, \mathrm{Ar}\right), 8.07\left(2 \mathrm{H}, \mathrm{d},{ }^{3} \mathrm{~J}_{H H} 7.5 \mathrm{~Hz}\right.$, carbazole), $8.14(2 \mathrm{H}, \mathrm{d}$, ${ }^{3} J_{H H} 8.7 \mathrm{~Hz}, \mathrm{Ar}$ ). Anal. Calcd for $\mathrm{C}_{38} \mathrm{H}_{37} \mathrm{~N}_{3} \mathrm{OS}$ (583.78): C, 78.18; $\mathrm{H}, 6.39 ; \mathrm{N}, 7.20 ; \mathrm{S}, 5.49 \%$. Found: $\mathrm{C}, 78.14 ; \mathrm{H}$, $6.33 ; \mathrm{N}, 7.12 ; \mathrm{S}, 5.39 \%$.

4-\{[4-(9H-Carbazol-9-yl)phenyl]ethenyl\}-2-hexadecyloxy-6-[2-(thiophen-2-yl)ethenyl]pyrimidine (15). Yellow powder, yield $63 \% 0.4 \mathrm{~g}$, mp $29-30{ }^{0} \mathrm{C} .{ }^{1} \mathrm{H}$ NMR: $\delta_{\mathrm{H}} 0.87\left(3 \mathrm{H}, \mathrm{t},{ }^{3} \mathrm{~J}_{\mathrm{HH}} 6.3 \mathrm{~Hz}, \mathrm{CH}_{3}\right), 1.25\left(28 \mathrm{H}, \mathrm{m}, 14 \mathrm{CH}_{2}\right), 4.22(2 \mathrm{H}$, $\left.\mathrm{t},{ }^{3} \mathrm{~J}_{\mathrm{HH}} 6.6 \mathrm{~Hz}, \mathrm{OCH}_{2}\right), 7.21(6 \mathrm{H}: 1 \mathrm{H}$, thiophene, $2 \mathrm{H}$, carbazole, $1 \mathrm{H}$, pyrimidine, $1 \mathrm{H}, \mathrm{CH}=, 1 \mathrm{H}, \mathrm{CH}=, \mathrm{m}), 7.41(4 \mathrm{H}$ : $2 \mathrm{H}$, carbazole, $1 \mathrm{H}, \mathrm{CH}=, 1 \mathrm{H}, \mathrm{CH}=, \mathrm{m}), 7.49\left(2 \mathrm{H}, \mathrm{d},{ }^{3} J_{H H} 7.2 \mathrm{~Hz}\right.$, carbazole), $7.52\left(1 \mathrm{H}, \mathrm{d},{ }^{3} J_{H H} 3.3 \mathrm{~Hz}\right.$, thiophene), $7.69\left(1 \mathrm{H}, \mathrm{d},{ }^{3} \mathrm{~J}_{H H} 3.3 \mathrm{~Hz}\right.$, thiophene), $7.86\left(2 \mathrm{H}, \mathrm{d},{ }^{3} \mathrm{~J}_{\mathrm{HH}} 8.4 \mathrm{~Hz}, \mathrm{Ar}\right), 8.07\left(2 \mathrm{H}, \mathrm{d},{ }^{3} \mathrm{~J}_{H H} 7.5 \mathrm{~Hz}\right.$, carbazole), $8.14(2 \mathrm{H}, \mathrm{d}$, ${ }^{3} J_{H H} 8.7 \mathrm{~Hz}, \mathrm{Ar}$ ). Anal. Calcd for $\mathrm{C}_{46} \mathrm{H}_{53} \mathrm{~N}_{3} \mathrm{OS}$ (695.99): C, 79.38; H, 7.68; N, 6.04; S, 4.61\%. Found: C, 79.31; H, 7.60; N, 5.93; S, 4.48\%.

4-\{[4-(9H-Carbazol-9-yl)phenyl]ethenyl\}-2-hexadecyloxy-6-[2-(thiophen-3-yl)ethenyl]pyrimidine (16). Yellow powder, yield 58\%, 0.36g, mp 28-30 ${ }^{\circ} \mathrm{C} .{ }^{1} \mathrm{H}$ NMR: $\delta_{\mathrm{H}} 0.87\left(3 \mathrm{H}, \mathrm{t},{ }^{3} \mathrm{~J}_{\mathrm{HH}} 6.3 \mathrm{~Hz}, \mathrm{CH}_{3}\right), 1.25\left(28 \mathrm{H}, \mathrm{m}, 14 \mathrm{CH}_{2}\right), 4.22$ $\left(2 \mathrm{H}, \mathrm{t}, 3^{3} \mathrm{HH} 6.6 \mathrm{~Hz}, \mathrm{OCH}_{2}\right), 7.23(6 \mathrm{H}: 1 \mathrm{H}$, thiophene, $2 \mathrm{H}$, carbazole, $1 \mathrm{H}$, pyrimidine, $1 \mathrm{H}, \mathrm{CH}=, 1 \mathrm{H}, \mathrm{CH}=, \mathrm{m}), 7.41$ $(4 \mathrm{H}$ : $2 \mathrm{H}$, carbazole, $1 \mathrm{H}, \mathrm{CH}=, 1 \mathrm{H}, \mathrm{CH}=\mathrm{m}), 7.49\left(2 \mathrm{H}, \mathrm{d},{ }^{3} J_{H H} 7.2 \mathrm{~Hz}\right.$, carbazole), $7.51\left(1 \mathrm{H}, \mathrm{d}, 3^{3} \mathrm{JH}_{3.3 \mathrm{~Hz}} 3\right.$. thiophene), $7.69\left(1 \mathrm{H}, \mathrm{d},{ }^{3} \mathrm{~J}_{H H} 3.3 \mathrm{~Hz}\right.$, thiophene), $7.86\left(2 \mathrm{H}, \mathrm{d},{ }^{3} \mathrm{~J}_{H H} 8.4 \mathrm{~Hz}, \mathrm{Ar}\right), 8.06\left(2 \mathrm{H}, \mathrm{d},{ }^{3} \mathrm{JHH}_{H} 7.5 \mathrm{~Hz}\right.$, carbazole), $8.14\left(2 \mathrm{H}, \mathrm{d},{ }^{3} \mathrm{~J}_{\mathrm{HH}} 8.7 \mathrm{~Hz}\right.$, Ar). Anal. Calcd for $\mathrm{C}_{46} \mathrm{H}_{53} \mathrm{~N}_{3} \mathrm{OS}$ (695.99): C, 79.38; H, 7.68; N, 6.04; S, 4.61\%. Found: C, 79.33; H, 7.62; N, 5.91; S, 4.48\%.

\section{4-[(N-Ethylcarbazol-3-yl)ethenyl]-2-hexyloxy-6-[2-(thiophen-2-yl)ethenyl]pyrimidine (17)}

Yellow powder, yield 60\%, $0.13 \mathrm{~g}, \mathrm{mp} 63-65{ }^{\circ} \mathrm{C} .{ }^{1} \mathrm{H}$ NMR: $\delta_{\mathrm{H}} 0.89\left(6 \mathrm{H}, \mathrm{t},{ }^{3} \mathrm{~J}_{H H} 6.9 \mathrm{~Hz}, 2 \mathrm{CH}_{3}\right), 1.34\left(4 \mathrm{H}, \mathrm{m}, 2 \mathrm{CH}_{2}\right)$, $1.55\left(2 \mathrm{H}, \mathrm{m}, \mathrm{OCH}_{2} \mathrm{CH}_{2} \mathrm{CH}_{2} \mathrm{C}\right), 1.82\left(2 \mathrm{H}, \mathrm{m}, \mathrm{OCH}_{2} \mathrm{CH}_{2} \mathrm{C}\right), 4.21\left(2 \mathrm{H}, \mathrm{t},{ }^{3} \mathrm{~J}_{H H} 4.8 \mathrm{~Hz}, \mathrm{NCH}_{2}\right), 4.23\left(2 \mathrm{H}, \mathrm{t},{ }^{3} \mathrm{~J}_{H H} 6.6\right.$ $\left.\mathrm{Hz}, \mathrm{OCH}_{2}\right), 6.76,6.81\left(2 \mathrm{H}, \mathrm{d},{ }^{3} \mathrm{~J}_{H H} 15.3 \mathrm{~Hz}, 2 \mathrm{CH}=\right), 7.05\left(1 \mathrm{H}, \mathrm{t},{ }^{3} \mathrm{~J}_{H H} 4.2 \mathrm{~Hz}\right.$, thiophene), $7.22(1 \mathrm{H}, \mathrm{s}, \mathrm{pyrimidine})$, $7.31\left(1 \mathrm{H}, \mathrm{d},{ }^{3} \mathrm{~J}_{\mathrm{HH}} 4.2 \mathrm{~Hz}\right.$, thiophene), $7.52\left(1 \mathrm{H}, \mathrm{d},{ }^{3} \mathrm{~J}_{\mathrm{HH}} 5.4 \mathrm{~Hz}\right.$, thiophene), 7.68-7.71 (3H, m, carbazole), 7.99-8.03 $\left(2 \mathrm{H}, \mathrm{m}\right.$, carbazole), 8.04, $8.09\left(2 \mathrm{H}, \mathrm{d},{ }^{3} \mathrm{~J}_{H H} 15.6 \mathrm{~Hz}, 2 \mathrm{CH}=\right), 8.16\left(1 \mathrm{H}, \mathrm{d},{ }^{3} \mathrm{~J}_{H H} 7.8 \mathrm{~Hz}\right.$, carbazole), $8.6(1 \mathrm{H}, \mathrm{s}$, carbazole). ${ }^{13}$ C NMR: $\delta_{c} 13.6,14.1,22.7,29.3,31.6,37.9,67.0,107.9,108.9,109.5,113.3,119.4,121.0,122.6$, $122.8,124.5,124.7,125.7,126.0,126.3,129.5,129.9,132.7,135.6,140.6,140.9,142.1,164.5,164.8,170.0$. Anal. Calcd for $\mathrm{C}_{32} \mathrm{H}_{37} \mathrm{~N}_{3} \mathrm{OS}$ (507.69): C, 75.70; H, 6.55; N, 8.28; S, 6.32\%. Found: $\mathrm{C}, 75.66 ; \mathrm{H}, 6.48 ; \mathrm{N}, 8.18 ; \mathrm{S}$, $6.18 \%$.

2-[(2-Ethylhexyl)oxy]-4-\{[4-(N-ethyloxycarbazol-3-yl)ethenyl]l\}-6-[2-(thiophen-2-yl)ethenyl]pyrimidine (18). Yellow viscous substance, yield 63\%, $0.24 \mathrm{~g} .{ }^{1} \mathrm{H}$ NMR: $\delta_{\mathrm{H}} 0.94\left(9 \mathrm{H}, \mathrm{m}, 3 \mathrm{CH}_{3}\right), 1.32\left(8 \mathrm{H}, \mathrm{m}, 4 \mathrm{CH}_{2}\right), 1.57(1 \mathrm{H}, \mathrm{m}$, $\left.\mathrm{OCH}_{2} \underline{\mathrm{CHC}}\right), 4.21\left(2 \mathrm{H}, \mathrm{t},{ }^{3} \mathrm{~J}_{\mathrm{HH}} 4.8 \mathrm{~Hz}, \mathrm{NCH}_{2}\right), 4.30\left(2 \mathrm{H}, \mathrm{d},{ }^{3} \mathrm{~J}_{\mathrm{HH}} 6.6 \mathrm{~Hz}, \mathrm{OCH}_{2}\right), 6.78,6.83\left(2 \mathrm{H}, \mathrm{d}, 3^{3} \mathrm{HH}_{15} 15.3 \mathrm{~Hz}, 2 \mathrm{CH}=\right)$, $7.05\left(1 \mathrm{H}, \mathrm{t},{ }^{3} \mathrm{~J}_{H H} 4.5 \mathrm{~Hz}\right.$, thiophene), $7.23\left(1 \mathrm{H}, \mathrm{s}\right.$, pyrimidine), $7.32\left(1 \mathrm{H}, \mathrm{d},{ }^{3} \mathrm{~J}_{H H} 4.5 \mathrm{~Hz}\right.$, thiophene), $7.42(1 \mathrm{H}, \mathrm{d}$, ${ }^{3} J_{H H} 3.6 \mathrm{~Hz}$, thiophene),7.68 $\left(3 \mathrm{H}, \mathrm{m}\right.$, carbazole), 7.50-7.53 $\left(2 \mathrm{H}, \mathrm{m}\right.$, carbazole), 7.99, $8.04\left(2 \mathrm{H}, \mathrm{d},{ }^{3} \mathrm{~J}_{H H} 15.6 \mathrm{~Hz}\right.$, $2 \mathrm{CH}=)$, 8.08, $8.12\left(1 \mathrm{H}, \mathrm{d},{ }^{3} \mathrm{~J}_{\mathrm{HH}} 8.1 \mathrm{~Hz}\right.$, carbazole), $8.2\left(1 \mathrm{H}, \mathrm{s}\right.$, carbazole). Anal. Calcd for $\mathrm{C}_{34} \mathrm{H}_{37} \mathrm{~N}_{3} \mathrm{OS}$ (535.74): $\mathrm{C}$, 76.22; H, 6.96; N, 7.84; S, 5.99\%. Found: C, 76.15; H, 6.88; N, 7.75; S, 5.86\%.

4-[(N-Ethylcarbazol-3-yl)ethenyl]-2-hexadecyloxy--6-[2-(thiophen-2-yl)ethenyl]pyrimidine (19). Yellow viscous substance, yield 65\%, $1.01 \mathrm{~g} .{ }^{1} \mathrm{H}$ NMR: $\delta_{\mathrm{H}} 0.86\left(6 \mathrm{H}, \mathrm{t},{ }^{3} \mathrm{~J}_{\mathrm{HH}} 6.3 \mathrm{~Hz}, 2 \mathrm{CH}_{3}\right), 1.24\left(24 \mathrm{H}, \mathrm{m}, 12 \mathrm{CH}_{2}\right), 1.48(2 \mathrm{H}$, $\left.\mathrm{m}, \mathrm{OCH}_{2} \mathrm{CH}_{2} \mathrm{CH}_{2} \mathrm{C}\right), 1.81\left(2 \mathrm{H}, \mathrm{m}, \mathrm{OCH}_{2} \mathrm{CH}_{2} \mathrm{CH}_{2}\right), 4.21\left(2 \mathrm{H}, \mathrm{t},{ }^{3} J_{H H} 4.8 \mathrm{~Hz}, \mathrm{NCH}_{2}\right), 4.44\left(2 \mathrm{H}, \mathrm{t}, 3^{3} \mathrm{HH}_{6.6 \mathrm{~Hz}, \mathrm{OCH}}\right)$, 6.71, $6.76\left(2 \mathrm{H}, \mathrm{d},{ }^{3} \mathrm{~J}_{H H} 15.3 \mathrm{~Hz}, 2 \mathrm{CH}=\right), 7.04\left(1 \mathrm{H}, \mathrm{t},{ }^{3} J_{H H} 4.2 \mathrm{~Hz}\right.$, thiophene), 7.21, $7.22\left(1 \mathrm{H}, \mathrm{d},{ }^{3} J_{H H} 3.6 \mathrm{~Hz}\right.$, thiophene), $7.23\left(1 \mathrm{H}, \mathrm{s}\right.$, pyrimidine), $7.30,7.31\left(1 \mathrm{H}, \mathrm{d},{ }^{3}{ } \mathrm{HH} 5.1 \mathrm{~Hz}\right.$, thiophene), 7.50-7.55 (3H, m, carbazole), 7.68-7.71 (2H, m, carbazole), 7.98, $8.03\left(2 \mathrm{H}, \mathrm{d},{ }^{3} \mathrm{~J}_{H H} 15.3 \mathrm{~Hz}, 2 \mathrm{CH}=\right), 7.98,8,01\left(1 \mathrm{H}, \mathrm{d},{ }^{3} \mathrm{~J}_{\mathrm{HH}} 8.6 \mathrm{~Hz}\right.$, carbazole), $8.08\left(1 \mathrm{H}, \mathrm{s}\right.$, carbazole). Anal. Calcd for $\mathrm{C}_{42} \mathrm{H}_{53} \mathrm{~N}_{3} \mathrm{OS}$ (647.95): C, 77.85; H, 8.24; N, 6.49; S, 4.95\%. Found: C, 77.79; H, 8.18; N, 6.39; S, 4.81\%. 


\section{Acknowledgements}

This work was financially supported by the Ministry of Education and Science of the Russian Federation (grant 012011461916) and Russian Foundation for Basic Research (14-03-96003r_ural_a).

\section{References}

1. Kanibolotsky, A. L.; Perepichka, I. F.; Skabara, P. J. Chem. Soc. Rev. 2010, 39, 2695. http://dx.doi.org/10.1039/b918154g

2. Yen, Y. S.; Chou, H. H.; Chen, Y. C.; Hsu, C. Y.; Lin, J. T. J.Mater.Chem. 2012, 22, 8734. http://dx.doi.org/10.1039/c2jm30362k

3. Pron, A.; Leclerc, M. Prog. Polym. Sci. 2013, 38, 1815. http://dx.doi.org/10.1016/j.progpolymsci.2013.08.007

4. Organic electronics: materials, manufacturing and applications; Klauk, H. Eds.; Wiley-VCH: Weinheim, 2006; p 33.

5. Mizuno, J.; Watanabe, T.; Toguchi, S.; Furukawa, K. In Organic Electronics Materials and Devices; Ogawa, S. Eds.; Springer: Japan, 2015; p 43. http://dx.doi.org/10.1007/978-4-431-55654-1

6. Grimsdale, A. C.; Chan, K. L.; Martin, R. E.; Jokisz, P. G.; Holmes, A. B. Chem. Rev. 2009, $109,897$. http://dx.doi.org/10.1021/cr000013v

7. Achelle, S.; Barsella, A.; Caro, B.; Robin-le Guen, F.; RSC Adv. 2015, 5, 39218. http://dx.doi.org/10.1039/C5RA05736A

8. Zhu, L.; Younes, A. H.; Yuan, Z.; Clark, R. J. J. Photochem. Photobiol. A: Chem. 2015, 311, 1. http://dx.doi.org/10.1016/i.jphotochem.2015.05.008

9. Hadziioannou, G.; Hutten, P.F.V. Semiconducting Polymers: Chemistry, Physics and Engineering; WILEYVCH: Weinheim, 2007; p 120.

10. Sirringhaus, H. Adv. Mater. 2005, 17, 2411 http://dx.doi.org/10.1002/adma.200501152

11. Inzelt, G. Conducting Polymers. A new Era in Electrochemistry; Springer: Berlin, 2008; p 68. http://dx.doi.org/10.1007/978-3-540-75930-0

12. Mamtimin, X.; Aikebaierjiang, A.; Alifujiang, M.; Tuerxun, T.; Kurban, Z.; Sun, W. F.; Nurulla I. J. Polym. Res. 2011, 18, 105.

http://dx.doi.org/10.1007/s10965-010-9396-2

13. Leclerc, N.; Chávez, P.; Ibraikulov, O. A.; Heiser, T.; Lévêque, P. Polymer 2016, 8, 1, 11. http://dx.doi.org/10.3390/polym8010011

14. Wong, K.-T.; Hung, T. S.; Lin, Y.; Wu, C.-C.; Lee, G.-H.; Peng, S.-M.; Chou, C. H.; Su, Y. O. Org. Lett. 2002, 4, 513.

http://dx.doi.org/10.1021/ol017066z

15. Itami, K.; Yamazaki, D.; Yoshida, J. J. Am. Chem. Soc. 2004, 126, 15396. http://dx.doi.org/10.1021/ja044923w

16. Li, L.; Tian, Y.-P.; Yang, J.-X.; Sun, P.-P.; Wu, J.-Y.; Zhou, H.-P.; Zhang, S.-Y.; Jin, B.-K.; Xing, X.-J.; Wang, C.K.; Li, M.; Cheng, G.-H.; Tang, H.-H.; Huang, W.-H.; Tao, X.-T.; Jiang, M.-H. Chem. Asian. J. 2009, 4, 668. 
http://dx.doi.org/10.1002/asia.200800402

17. Ortiz, R. P.; Casado, J.; Hernández, V.; LópezNavarrete, J. T.; Letizia, J. A.; Ratner, M. A.; Facchetti, A.; Marks, T. J. Chem. Eur. J. 2009, 15, 5023.

http://dx.doi.org/10.1002/chem.200802424

18. Liu, Z.; Chen, T.; Liu, B.; Huang, Z.-L.; Huang, T.; Li, A.; Xu, Y.; Qin,J. J. Mater. Chem. 2007, $17,4685$. http://dx.doi.org/10.1039/b707909e

19. Achelle, S.; Ramondenc, Y.; Marsais, F.; Plé, N. Eur. J. Org. Chem. 2008, 3129. http://dx.doi.org/10.1002/ejoc.200800139

20. Liu, Z.; Shao, P.; Huang, Z.; Liu, B.; Chen, T.; Qin, J. Chem. Commun. 2008, 2260. http://dx.doi.org/10.1039/b718147g

21. Brown, D. J.; Mason, S. F. The Chemistry of Heterocyclic compounds. XVI. The Pyrimidines; A. Weissberger, 1962; p. 774.

22. Brown, D. J.; Evans, R. F.; Cowden, W. B.; Fenn, M. D. The Chemistry of Heterocyclic compounds. XVI. The Pyrimidines; Weissberger, A.; Taylor E. C. Eds.; New-York-Chichester-Brisbane-Toronto-Singapore, 1985; p 770.

23. Kim, H. M.; Cho, B. R. Acc. Chem. Res. 2009, 42, 7, 863. http://dx.doi.org/10.1021/ar800185u

24. Chen, D.; Zhong, C.; Dong, X.; Liu, Z.; Qin, J. J. Mater. Chem. 2012, 22, 4343. http://dx.doi.org/10.1039/c2jm14766a

25. Picot, A.; D’Aleo, A.; Baldeck, P. L.; Grichine, A.; Duperray, A.; Andraud, C.; Maury, O. J. Am. Chem. Soc. 2008, 130, 1532.

http://dx.doi.org/10.1021/ja076837c

26. Frederiksen, P. K.; Jorgensen, M.; Ogilby P. R. J. Am. Chem. Soc. 2001, 123, 1215. http://dx.doi.org/10.1021/ja003468a

27. Larson, D. R.; Zipfel, W.; Williams, R. M.; Clark, S. W.; Bruchez, M. P.; Wise, F. W.; Webb, W. W. Science 2003, 300, 1434.

http://dx.doi.org/10.1126/science.1083780

28. Shima, S.; Ilagan, R. P.; Gillespie, N.; Sommer, B. J.; Hiller, R. G.; Sharples, F. P.; Frank, H. A.; Birge, R. R. J. Phys. Chem. A 2003, 107, 8052. http://dx.doi.org/10.1021/ip022648z

29. Martin, R. E.; Geneste, F.; Holmes A. B. C. R. Acad. Sci. Paris, t. 1, Série IV 2000, 447.

30. Kanaparthi, R. K.; Kandhadi, J.; Giribabu, L. Tetrahedron 2012, 68, 8383. http://dx.doi.org/10.1016/i.tet.2012.06.064

31. Komissarova, E. A.; Lunegov, I. V.; Shklyaeva, E. V.; Abashev, G. G. Chem. Heterocyclic Comp. 2016, 52, 257.

http://dx.doi.org/10.1007/s10593-016-1871-1

32. Kaur, M.; Cho, M. J.; Choi, D. H. Dyes Pigments 2016, 125, 1. http://dx.doi.org/10.1016/j.dyepig.2015.09.030

33. Gunathilake, S. S.; Magurudeniya, H. D.; Huang, P.; Nguyen, H.; Rainbolt, E. A.; Stefan, M. C., Biewer M. C. Polym. Chem. 2013, 4, 5216. http://dx.doi.org/10.1039/c3py00137g

34. Kaur, M.; Ahn, Y.-H.; Choi, K.; Cho, M. J.; Choi,D. H. Org. Biomol. Chem. 2015, 13, 7149. http://dx.doi.org/10.1039/C5OB00907C

35. Kato, S.; Yamada, Y.; Hiyoshi, H.; Umezu, K.; Nakamura, Y. J. Org. Chem. 2015, 80, 9076. 
http://dx.doi.org/10.1021/acs.joc.5b01409

36. Abashev G., Sosnin E., Shklyaeva E., Ustalova T., Osorgina I., Romanova V. Phys. Status Solidi C 2012; 5, 1127.

http://dx.doi.org/10.1002/pssc.201100713

37. Li, Q.; Cui, L.-S.; Zhong, C.; Jiang, Z.-Q.; Liao, L.-S. Org. Lett. 2014, 16, 1622.

http://dx.doi.org/10.1021/ol5002494

38. Coughlin,_J. E.; Henson, Z. B.; Welch, G. C.; Bazan, G. C. Acc. Chem. Res. 2014, 47,1, 257. http://dx.doi.org/10.1021/ar400136b

39. Wang, J.; deJeu, W.H.; Ziener, U.; Polinskaya, M.S.; Ponomarenko, S.A.; Ruecker, U.; Ruderer, M.A.; Herzig, E. M.; Muller-Buschbaum, P.; Moeller, M.; Mourran, A.; Langmuir 2014, 30, 2752.

http://dx.doi.org/10.1021/la404918b

40. Sosnin, E. A.; Shklyaeva, E. V.; Abashev, G. G. All-Russia Conference: "Organic synthesis: chemistry and technology", Ekaterinburg, Russia, June 4-8, 2012: Abstract No. Y-40.

41. Achelle, S.; Nouira, I.; Pfaffinger, B.; Ramondenc, Y.; Plé, N.; Rodríguez-López, J. J. Org. Chem. 2009, 74, 3711.

http://dx.doi.org/10.1021/jo900107u

42. Hunt, K. K.; Mcomie, J. F. W.; Sayer, E. R. J. Chem. Soc. 1959, 527.

http://dx.doi.org/10.1039/JR9590000525

43. Sosnin, E. A. Ph.D. Thesis, Institute of Organic Chemistry of Russian Academy of Sciensis, Ufa, 2014.

44. Mutai, T.; Tomoda, H.; Ohkawa, T.; Yabe, Y.; Araki, K. Angew. Chem. 2008, 120, 9664. http://dx.doi.org/10.1002/ange.200803975

45. Stasyuk, A. J.; Banasiewicz, M.; Cyranski, M. K.; Gryko, D. T. J. Org. Chem. 2012, 77, 5552. http://dx.doi.org/10.1021/jo300643w

46. Lakowicz, J. R. Principles of Fluorescence Spectroscopy, 3th Edn.; Springer, 2006; pp 6-9.

47. Kraayenhof, R.; Visser,A. J. W. G.; Gerritsen, H. Fluorescence Spectroscopy, Imaging and Probes: New Tools in Chemical, Physical and Life Sciences; Springer Science \& Business Media, 2012; p 213.

48. Meng, H.; Zheng, J.; Lovinger, A.J.;Wang, B.-C.;Van Patten, P.G.; Bao, Z. Chem. Mater. 2003, $15,1778$. http://dx.doi.org/10.1021/cm020866z

49. Naarmann, H.; Strohriegl. P. Handbook of Polymers. Part B. Principles of carrier transport; New York: Marcel Dekker, 1992; p 1353.

50. Sarac, A. ; Ates, M.; Parlak. E.; J. Applied Electrochem. 2006, 36. 889. http://dx.doi.org/10.1007/s10800-006-9145-8 